\title{
The aerosol distribution in Europe derived with the Community Multiscale Air Quality (CMAQ) model: comparison to near surface in situ and sunphotometer measurements
}

\author{
V. Matthias \\ GKSS Research Center, Institute for Coastal Research, Max-Planck-Straße 1, 21502 Geesthacht, Germany
}

Received: 24 September 2007 - Published in Atmos. Chem. Phys. Discuss.: 29 January 2008

Revised: 7 May 2008 - Accepted: 10 July 2008 - Published: 1 September 2008

\begin{abstract}
The aerosol distribution in Europe was simulated with the Community Multiscale Air Quality (CMAQ) model system version 4.5 for the years 2000 and 2001. The results were compared with daily averages of $\mathrm{PM}_{10}$ measurements taken in the framework of EMEP and with aerosol optical depth (AOD) values measured within AERONET. The modelled total aerosol mass is typically about $30-60 \%$ lower than the corresponding measurements. However a comparison of the chemical composition of the aerosol revealed a considerably better agreement between the modelled and the measured aerosol components for ammonium, nitrate and sulfate, which are on average only $15-20 \%$ underestimated. Sligthly worse agreement was determined for sea salt, that was only avaliable at two sites. The largest discrepancies result from the aerosol mass which was not chemically specified by the measurements. The agreement between measurements and model is better in winter than in summer. The modelled organic aerosol mass is higher in summer than in winter but it is significantly underestimated by the model. This could be one of the main reasons for the discrepancies between measurements and model results. The other is that primary coarse particles are underestimated in the emissions. The probability distribution function of the $\mathrm{PM}_{10}$ measurements follows a log-normal distribution at most sites. The model is only able to reproduce this distribution function at non-coastal low altitude stations. The AOD derived from the model results is 20-70\% lower than the values observed within AERONET. This is mainly attributed to the missing aerosol mass in the model. The day-to-day variability of the AOD and the log-
\end{abstract}

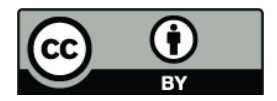

Correspondence to: V. Matthias (volker.matthias@gkss.de) normal distribution functions are quite well reproduced by the model. The seasonality on the other hand is underestimated by the model results because better agreement is achieved in winter.

\section{Introduction}

Aerosol particles belong to those constituents of the Earth's atmosphere that show a highly variable distribution in space and time. Most of the particles can be found in the well mixed planetary boundary layer (PBL) and close to ground, where the main sources of aerosol particles are located. On the other hand deep convection and frontal systems can lift large amounts of particles into the free troposphere where they can be transported over very large distances. Although globally most of the aerosols are of natural origin (sea salt and dust), regionally anthropogenic aerosols, either directly emitted (primary aerosols) or generated from gaseous precursors (secondary aerosols), can dominate the aerosol chemical composition.

Aerosols largely determine the optical properties of the cloud free atmosphere by scattering and absorbing sunlight. They additionally influence the reflectivity and lifetime of clouds by acting as condensation nuclei and affecting the cloud droplet size spectrum (first and second indirect aerosol effect Twomey, 1977; Ramaswamy et al., 2001). This is one of the reasons why much attention has been paid in recent years to correctly represent aerosol particles in general circulation models (Penner et al., 2001; Kinne et al., 2003; Textor et al., 2006). However, on the regional scale aerosols are so far mainly seen under the air quality perspective. In

Published by Copernicus Publications on behalf of the European Geosciences Union. 
2005 EU legislation introduced threshold values for aerosol particles smaller than $10 \mu \mathrm{m}\left(\mathrm{PM}_{10}\right)$ to minimize respiratory diseases and other health risks associated with the inhalation of small particles. Among these are also carcinogenic substances that are transported as particles or on the surface of particles. Polyaromatic hydrocarbons (PAHs) belong to this group and the EU fourth framework directive (EC, 2005) includes threshold values for one the the most harmful PAHs, benzo(a)pyrene (B(a)P).

This paper investigates the ability of the regional Eulerian chemistry transport model (CMAQ) to simulate the aerosol distribution in Europe during the years 2000 and 2001 on a scale of $54 \times 54 \mathrm{~km}^{2}$ and over the North Sea on a scale of $18 \times 18 \mathrm{~km}^{2}$. Additional to the more conventional comparison of the the simulated aerosol mass density to measurements at near surface EMEP background stations, special attention is paid to the optical effects of the aerosol particles. Aerosol optical depth (AOD) values derived from the chemically resolved aerosol mass in the model is compared to AERONET sunphotometer measurements.

Measurements of the inorganic aerosol (IA) species ammonium, nitrate and sulfate at ground level with daily resolution are also compared to the model results. At two stations, Melpitz in Germany and Birkenes in Norway, sea salt was taken into account as well. Besides a statistical evaluation in terms of bias and correlations, the probability distribution functions of the $\mathrm{PM}_{10}$ and $\mathrm{AOD}$ values are presented.

\section{Model description}

\subsection{Chemistry transport model}

CMAQ has been developed under the leadership of the Atmospheric Modeling Division of the Environmental Protection Agency (EPA) National Exposure Research Laboratory in Research Triangle Park, North Carolina, USA. The modeling system and its source codes are freely available for use by air quality regulators, policy makers, industry, and scientists to address multiscale, multi-pollutant air quality concerns. It includes a chemistry transport model that currently allows for the simulation of concentrations and deposition of the major air pollutants and particulate matter. Because of its generalized coordinate system and its advanced nesting features CMAQ can be used to study the behaviour of air pollutants from local to regional scales. A detailed description of the model system is given by Byun and Ching (1999) and more recently by Byun and Schere (2006).

The model includes gas phase, aerosol and aqueous chemistry. In this study, the CBM4 mechanism (Gery et al., 1989) is used for the gas phase chemistry. The aerosol is represented by three size modes (Aitken, accumulation and coarse mode), each of them is assumed to have a lognormal distribution (Binkowski and Roselle, 2003). The model distinguishes between 10 different chemical aerosol components, namely sulfate, ammonium, nitrate, sodium, chloride, elemental carbon, organic carbon with the three subcomponents primary, secondary anthropogenic and secondary biogenic, and soil. Unspecified anthropogenic aerosols and aerosol water are additionally kept as separate components.

Secondary inorganic aerosol (SIA) is generated by nucleation processes from its precursors to form nitrate, ammonium and sulfate aerosols. Secondary organic aerosol (SOA) can be formed from aromatics (anthropogenic organic aerosols) and terpenes (biogenic organic aerosols) (Schell et al., 2001). In version 4.5 of CMAQ that was used for this study sea salt aerosol is parameterized according to wind speed above oceans but heterogeneous chemistry is not considered. The inclusion of sea salt is an important feature for $\mathrm{PM}_{10}$ studies in coastal regions that was not available in earlier CMAQ versions.

At the Institute for Coastal Research of the GKSS Research Centre Geesthacht currently an addition to CMAQ is being developed to study the trans-boundary transport of PAHs and their deposition within coastal regions. In a first step the carcinogenic benzo(a)pyrene $(\mathrm{B}(\mathrm{a}) \mathrm{P})$ is included in the aerosol scheme of the model version 4.5, the most recent CMAQ version at the time when the development was done. Because its transport and deposition is closely connected to that of other aerosol particles, in particular of organic aerosols, this study aims at giving further insight in the results for $\mathrm{B}(\mathrm{a}) \mathrm{P}$, too. The new PAH mechanism for CMAQ is described in Aulinger et al. (2007). The results for B(a)P are discussed in a separate paper ${ }^{1}$. The contribution of $\mathrm{B}(\mathrm{a}) \mathrm{P}$ to the total aerosol mass is negligible because of their low concentrations.

The CMAQ model is setup on a $54 \times 54 \mathrm{~km}^{2}$ grid for Europe and on a nested smaller domain with a $18 \times 18 \mathrm{~km}^{2}$ grid for the North Sea region. The latter will be used in future studies of PAH deposition into North Sea coastal regions. Special emphasis is laid on the representation of the planetary boundary layer to capture vertical transport and dispersion of atmospheric air pollution in coastal environments, where special circulation patterns (e.g. land sea breeze effects) can be of importance. Therefore, 30 vertical levels up to $100 \mathrm{hPa}$, with 20 levels below approx. $2500 \mathrm{~m}$ are used in a terrain following $\sigma$-pressure co-ordinate system. The lowest layer that represents ground level conditions is approx. $36 \mathrm{~m}$ thick.

\subsection{Emissions}

In the Models-3 framework, North American emissions are generated with the emissions model SMOKE (Houyoux and Vukovich, 1999). This model cannot be directly transferred to Europe because the geostatistical information, the

\footnotetext{
${ }^{1}$ Matthias, V., Aulinger, A., and Quante, M.: CMAQ simulations of the benzo(a)pyrene distribution in Europe in 2000 and 2001, Atmos. Environ., submitted, 2008.
} 
speciation of the emissions and the temporal evolution of the emissions are different in Europe and are currently not available in the needed formats. The emissions that were used to derive the results presented in this paper were provided by the Institute for Energy Economics and the Rational Use of Energy (IER), Stuttgart, Germany. They were calculated on the basis of EMEP (Vestreng and Klein, 2002) and the European Pollutant Emission Register (EPER, www.eper.cec.eu.int) annual country emissions and include the gaseous species $\mathrm{NO}_{\mathrm{x}}, \mathrm{CO}, \mathrm{SO}_{2}, \mathrm{NH}_{3}$, and 35 non-methane volatile organic compounds (NMVOCs) in RADM2 speciation (Stockwell et al., 1990). Aerosol particles were given as $\mathrm{PM}_{10}$ and $\mathrm{PM}_{2.5}$ primary emissions.

From the $50 \times 50 \mathrm{~km}^{2}$ grid used by EMEP, the emissions are adapted to the $54 \times 54 \mathrm{~km}^{2}$ grid, which is on a different map projection and then scaled down to the $18 \times 18 \mathrm{~km}^{2}$ grid. Information about the population density, roads and industrial plants are considered in both steps. A temporal development of the emissions based on information about e.g. traffic, heating and industrial production is also assumed. The IER emissions contain all anthropogenic sources described in the European inventories. The data was delivered with one hour resolution for the time period 1 January 2000 to 31 December 2000. For the 2001 model results, it was assumed that the emissions did not change compared to the year before. Details on the emissions model of IER are described in Friedrich and Reis (2004).

There was no information available about the origin of the primary particle emissions in the IER inventory. The fine particles $\left(\mathrm{PM}_{2.5}\right)$ were distributed to the main chemical components following a typical emission profile for particles of industrial origin that is used in SMOKE: sulfate 12\%, elemental carbon (EC) $2 \%$, organic carbon (OC) $1 \%$ and unspecified particles $85 \%$. Traffic emissions and those from residential heating have higher contributions of elemental and organic carbon, but no distinction between emission sectors could be made in the individual grid cells. The coarse particles were completely treated as unspecified particles. CMAQ divides them internally into soil (90\%) and other coarse particles $(10 \%)$.

Natural emissions are not included in the IER emissions, but to have more complete emissions specific natural emission data sets from global emission inventories were taken into account. These data sets are mostly used for global chemistry transport modeling and the emissions are typically given as monthly averages on a $1^{\circ} \times 1^{\circ}$ grid. Isoprene and terpenes as precursors of secondary organic aerosols were taken from the POET data base (Granier et al., 2005), while monthly particle emissions of elemental carbon and organic matter were taken from the Global Fire Emission Data base (GFED van der Werf et al., 2006) data set for the year 2000. Dust was considered using the Aerocom emission data set for the year 2000 (Dentener et al., 2006). All these global data sets were first spatially interpolated to the $54 \times 54 \mathrm{~km}^{2}$ grid and afterwards to the $18 \times 18 \mathrm{~km}^{2}$ grid. The monthly data was interpolated down to daily varying emissions. All emissions were kept the same in 2000 and 2001.

B(a)P emissions were taken from Denier van der Gon et al. (2005) who provided annual gridded emissions for Europe in 2000. The temporal disaggregation of the emissions will be described in detail by Aulinger et al. $(2008)^{2}$. The emissions from resendential heating, which is the most important source of $\mathrm{B}(\mathrm{a}) \mathrm{P}$, depend on the temperature at ground while traffic and industrial emissions are adapted to the temporal cycles of NO emissions.

\subsection{Meteorological fields}

The CMAQ chemical transport model can be run with meteorological fields defined on different types of grids. However, the most common procedure is to use the MM5 mesoscale atmospheric model (Grell et al., 1995), which can be directly linked to CMAQ via a Meteorology Chemistry Interface Preprocessor (MCIP, Otte, 1999). MM5 is widely used and tested in the scientific community (see e.g. Colle et al., 2003; Gilliam et al., 2006) which includes European groups that use this model to derive meteorological input fields for their atmospheric chemistry models (Jakobs et al., 1995; Sokhi et al., 2006). The model can be run with several combinations of physical parameterisations, depending on purpose and grid resolution. For this study, MM5 was operated with the more sophisticated parameterisations, because local features should be represented as good as possible. As microphysics scheme the Reisner 2 approach was used, it includes ice, snow and graupel as hydrometeors (Reisner et al., 1998). The planetary boundary layer (PBL) processes are based on a scheme which was originally used in the MRF model (Hong and Pan, 1996). It is based on the Troen and Mahrt (1986) nonlocal diffusion concept. A cumulus scheme that is formulated to allow also long term simulations is the Kain Fritsch 2 scheme (Kain and Fritsch, 1993; Kain, 2004). It considers conservation of mass, thermal energy, total moisture and momentum.

ERA40 reanalysis data on a $1^{\circ} \times 1^{\circ}$ grid served as meteorological initial and boundary conditions. A four dimensional data assimilation (FDDA) scheme which is implemeted in MM5 was used to keep the meteorological fields in the coarse grid as close as possible to the observations. Several tests were performed to define the best way of calculating the meteorology input for the chemistry transport simulation. During these tests, vertical profiles of temperature, humidity and wind were compared with regular radiosonde observations at 88 stations all over Europe. Closest agreement was achieved when the meteorological fields from the reanalysis were nudged every $12 \mathrm{~h}$. Wind components were nudged in all heights while temperature and humidity were only nudged

\footnotetext{
${ }^{2}$ Aulinger, A., Matthias, V., and Quante, M.: A temporal disaggregation of Benzo(a)Pyrene emissions and their application to a 3D Eulerian chemistry transport model, Atmos. Environ., in preparation, 2008.
} 


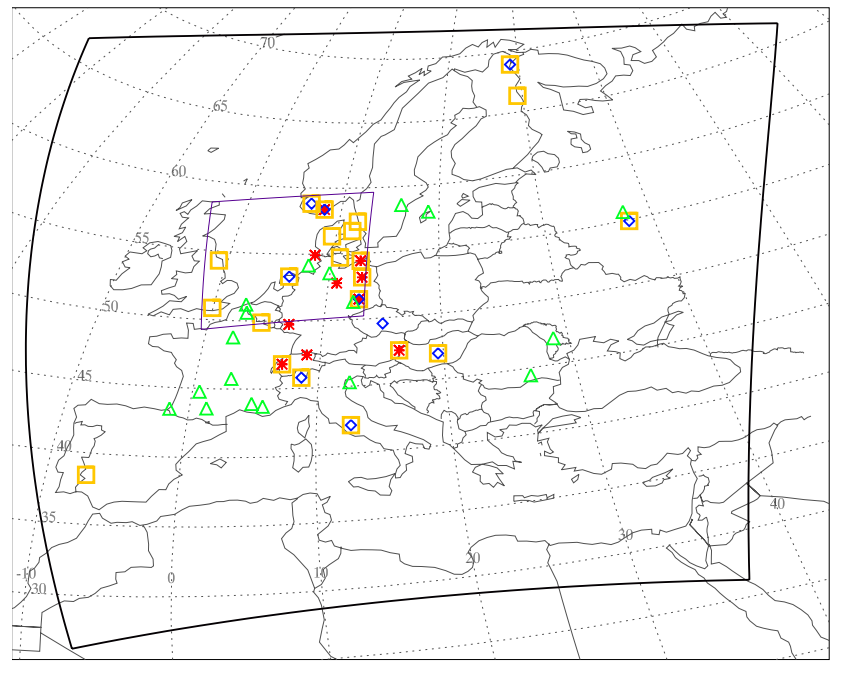

Fig. 1. Model domain for the $54 \times 54 \mathrm{~km}^{2}$ grid (outer thick line) and the nested $18 \times 18 \mathrm{~km}^{2}$ grid (inner thin line). Position of the measurement stations that were used for comparison. Symbols denote the type of measurement available at the individual sites. Red stars: $\mathrm{PM}_{10}$; blue diamonds: $\mathrm{NH}_{4}$ and $\mathrm{NO}_{3}$; yellow squares: $\mathrm{SO}_{4}$; green triangles: AOD.

above the PBL. Additionally, the Noah land surface module (Chen and Dudhia, 2001) was used to account for varying soil temperature and humidity. No nudging was applied in the nested grid. The simulations were done month by month with a spin up time of 4 days for each run and the sea surface temperature (SST) was varied accordingly. This procedure kept the influence of the initial conditions on the results of the runs negligible. A detailed description of the results will be given in a separate paper (Matthias et al., 2008 ${ }^{3}$ ).

\subsection{Initial and boundary conditions for CMAQ}

Depending on the model set-up, initial and boundary conditions can play an important role for the model results, particularly if the species under investigation can undergo long range transport or if special atmospheric conditions prolongate the atmospheric life time of some of the considered species.

For the simulations presented here, the boundary conditions were taken from MOZART (Horowitz et al., 2003; Niemeier et al., 2006) model results for the years 2000 and 2001. The data has a resolution of $1^{\circ} \times 1^{\circ}$ and one day. It includes the gas phase species $\mathrm{O}_{3}, \mathrm{O}, \mathrm{O}^{1} \mathrm{D}, \mathrm{CO}, \mathrm{NO}, \mathrm{NO}_{2}$, $\mathrm{SO}_{4}, \mathrm{HO}_{2}, \mathrm{OH}, \mathrm{PAN}, \mathrm{HCOH}$, isoprene, terpenes and $\mathrm{HNO}_{3}$. The modelled concentrations of these species were interpolated to the boundary of the CMAQ domain, which is one

\footnotetext{
${ }^{3}$ Matthias, V., Quante, M. and Aulinger, A.: Determination of the Optimum MM5 Configuration for CMAQ Simulations of Aerosol Bound Pollutants in Europe, Environmental Fluid Dynamics, submitted, 2008.
}

grid cell thick and updated hourly. However, the data varies only day by day as the MOZART model results do. Intercontinental transport of aerosol particles was not considered. Initial conditions are set once to average winter conditions on 25 December the year before each annual run starts. By this spin-up time of 7 days the influence of the initial conditions is kept very low.

\section{Results}

Annual runs for the years 2000 and 2001 were performed for Europe on the $54 \times 54 \mathrm{~km}^{2}$ grid and for the North Sea region on the $18 \times 18 \mathrm{~km}^{2}$ grid. The CMAQ output data was stored for all variables on an hourly basis so it could be analysed in detail and compared to the available measurements.

\subsection{Measurement data}

Because the model is run for a long time series and its spatial resolution for the whole continent is rather coarse, it is necessary to use routine measurements (instead of data from temporally limited field experiments) in remote areas (which is more representative for larger areas) for comparison with the model results. The EMEP program (Co-operative programme for monitoring and evaluation of the long range transmissions of air pollutants in Europe) provides such a network of measurement stations that is distributed over whole Europe with well documented measurements that follow a common standard. The measurement data is accessible via the EMEP web page (www.emep.int). All stations can be considered as background stations, which means that they are located at a minimum distance of approx. $10 \mathrm{~km}$ to large emission sources. Nevertheless, they can also be found in countries with frequently high air pollution as Germany and the Netherlands. Besides the gaseous photooxidants, EMEP provides daily resolved measurements of $\mathrm{PM}_{10}$, too. However for 2000 and 2001 the number of stations where a large data set is available is rather limited and focusses on Germany. The stations that were used for the comparison of ground based $\mathrm{PM}_{10}$ data are included in Table 1 and their location is displayed in Fig. 1.

To get further insight in the models ability to represent the chemical composition of the aerosol particles close to ground, chemically specified data from EMEP and the EU FP5 project CREATE was considered. The considered stations together with the measured quantities are given in Table 1. From EMEP mainly data for sulfate was available for 2000 and 2001 while for nitrate and ammonium only eight stations could be taken into account. The CREATE project provides more complete daily data including sea salt for 2000 at two stations that are located within the $18 \times 18 \mathrm{~km}^{2}$ North Sea grid. One of them, Birkenes (NO01) in south Norway is an EMEP station, here black carbon or elemental carbon (EC) and organic carbon (OC) are additionally measured 
Table 1. Location and altitude of the EMEP and CREATE PM $\mathrm{M}_{10}$, ammonium, nitrate, sulfate and sea salt measurement stations with data in 2000 and 2001.

\begin{tabular}{|c|c|c|c|c|c|c|c|}
\hline Code & Country & Station name & Species & Lat. $/{ }^{\circ} \mathrm{N}$ & Lon. $/^{\circ} \mathrm{E}$ & Alt./m & network \\
\hline AT02 & Austria & Illmitz & $\mathrm{PM}_{10}, \mathrm{SO}_{4}$ & 47.46 & 16.46 & 117 & EMEP \\
\hline $\mathrm{CH} 02$ & Switzerland & Payerne & $\mathrm{PM}_{10}, \mathrm{SO}_{4}$ & 46.82 & 6.95 & 489 & EMEP \\
\hline $\mathrm{CH} 03$ & Switzerland & Taenikon & $\mathrm{PM}_{10}$ & 47.48 & 8.9 & 539 & EMEP \\
\hline CZ03 & Czech Republic & Kosetice & $\mathrm{NH}_{4}, \mathrm{NO}_{3}, \mathrm{SO}_{4}$ & 49.58 & 15.08 & 534 & EMEP \\
\hline DE01 & Germany & Westerland & $\mathrm{PM}_{10}$ & 54.93 & 8.31 & 12 & EMEP \\
\hline DE02 & Germany & Langenbrügge & $\mathrm{PM}_{10}$ & 52.80 & 10.76 & 74 & EMEP \\
\hline DE04 & Germany & Deuselbach & $\mathrm{PM}_{10}$ & 49.77 & 7.05 & 490 & EMEP \\
\hline DE07 & Germany & Neuglobsow & $\mathrm{PM}_{10}, \mathrm{SO}_{4}$ & 53.17 & 13.03 & 62 & EMEP \\
\hline DE09 & Germany & Zingst & $\mathrm{PM}_{10}, \mathrm{SO}_{4}$ & 54.43 & 12.73 & 1 & EMEP \\
\hline DE44 & Germany & Melpitz & $\mathrm{NH}_{4}, \mathrm{NO}_{3}, \mathrm{SO}_{4}, \mathrm{Na}, \mathrm{Cl}$ & 51.52 & 12.92 & 86 & CREATE \\
\hline DK03 & Denmark & Tange & $\mathrm{SO}_{4}$ & 56.35 & 9.6 & 13 & EMEP \\
\hline DK05 & Denmark & Keldsnor & $\mathrm{SO}_{4}$ & 54.73 & 10.73 & 10 & EMEP \\
\hline DK08 & Denmark & Anholt & $\mathrm{SO}_{4}$ & 56.72 & 11.52 & 40 & EMEP \\
\hline ES11 & Spain & Barcarolla & $\mathrm{NH}_{4}, \mathrm{SO}_{4}$ & 38.47 & -6.92 & 393 & EMEP \\
\hline FI22 & Finland & Oulanka & $\mathrm{SO}_{4}$ & 66.32 & 29.4 & 310 & EMEP \\
\hline FR09 & France & Revin & $\mathrm{SO}_{4}$ & 49.9 & 4.63 & 390 & EMEP \\
\hline GB07 & Great Britain & Barcombe Mills & $\mathrm{SO}_{4}$ & 50.87 & -0.03 & 8 & EMEP \\
\hline GB14 & Great Britain & High Muffles & $\mathrm{SO}_{4}$ & 54.33 & -0.81 & 267 & EMEP \\
\hline HU02 & Hungary & K-Puszta & $\mathrm{NH}_{4}, \mathrm{NO}_{3}, \mathrm{SO}_{4}$ & 46.97 & 19.58 & 125 & EMEP \\
\hline IT01 & Italy & Montelibretti & $\mathrm{NH}_{4}, \mathrm{NO}_{3}, \mathrm{SO}_{4}$ & 42.1 & 12.63 & 48 & EMEP \\
\hline IT04 & Italy & Ispra & $\mathrm{NH}_{4}, \mathrm{NO}_{3}, \mathrm{SO}_{4}$ & 45.8 & 8.63 & 209 & EMEP \\
\hline NL09 & Netherlands & Kollumerwaard & $\mathrm{NH}_{4}, \mathrm{NO}_{3}, \mathrm{SO}_{4}$ & 53.33 & 6.28 & 1 & EMEP \\
\hline NO01 & Norway & Birkenes & $\mathrm{PM}_{10}, \mathrm{NH}_{4}, \mathrm{NO}_{3}, \mathrm{SO}_{4}, \mathrm{Na}, \mathrm{Cl}$ & 58.38 & 8.25 & 190 & EMEP \& CREATE \\
\hline NO08 & Norway & Skreadalen & $\mathrm{NH}_{4}, \mathrm{NO}_{3}, \mathrm{SO}_{4}$ & 58.82 & 6.72 & 475 & EMEP \\
\hline RU01 & Russia & Janiskoski & $\mathrm{NH}_{4}, \mathrm{NO}_{3}, \mathrm{SO}_{4}$ & 68.93 & 28.85 & 118 & EMEP \\
\hline RU18 & Russia & Danki & $\mathrm{NH}_{4}, \mathrm{NO}_{3}, \mathrm{SO}_{4}$ & 54.9 & 37.8 & 150 & EMEP \\
\hline SE02 & Sweden & Rörvik & $\mathrm{SO}_{4}$ & 57.42 & 11.93 & 10 & EMEP \\
\hline
\end{tabular}

since 2001. Melpitz (DE44) in central Germany $\left(51.52^{\circ} \mathrm{N}\right.$, $12.92^{\circ} \mathrm{E}$ ) is operated by the Institute for Tropospheric Research (IfT) Leipzig.

The uncertainty of aerosol mass measurements strongly depends on the method and on the chemical composition of the collected aerosol. Usually the collecting filters are weighed at 50\% relative humidity. According to Putaud et al. (2004) the aerosol will still contain water at this humidity. $\mathrm{PM}_{10}$ measurements at Ispra were on average $9 \%$ higher at $50 \%$ relative humidity than at $20 \%$. Most of the other error sources refer to losses of semivolatile compounds, particularly ammonium nitrate and carbonaceous aerosols, from the filters at temperatures higher than $20^{\circ} \mathrm{C}$. Neusüß et al. (2000) reported typical deviations of $\pm 20 \%$ between gravimetric methods and aerosol mass derived from number size distributions. If the inorganic chemical components were measured by ion chromatography, the error is usually within 10\% (Putaud et al., 2000). This method was used for the measurements collected within CREATE.

The optical properties of the aerosol in the entire atmospheric column are routinely observed within the Aerosol Robotic Network (AERONET, Holben et al., 1998). The network has grown to more than 200 stations world wide since the late 1990s and supplies a good continental coverage within Europe. The instruments can only deliver data during daytime and during totally cloud free periods, because they rely on extinction measurements of the direct and scattered solar radiation. In addition, the necessary annual calibration of the instruments usually needs some weeks during which they cannot be operated. Consequently the data coverage is limited to typically $100-250$ days per year. The AOD is typically measured at 4 , sometimes 7 wavelengths between $380 \mathrm{~nm}$ and $1020 \mathrm{~nm}$. The typical uncertainty in the measured AOD is 0.01 to 0.02 (Eck et al., 1999; Holben et al., 2001 ), representing a relative error of $3 \%$ to $20 \%$ for typical optical depths (0.1 to 0.3) in Europe. To achieve a good spatial coverage, stations with data on 15 days or more per year are in this study considered for comparison with the model results. An overview of the selected AERONET sations is given in Table 2 and their location is displayed in Fig. 1.

\section{2 $\mathrm{PM}_{10}$ at ground level}

Figure 2 displays the model derived ground level $\mathrm{PM}_{10}$ distribution over Europe in the year 2000. Highest $\mathrm{PM}_{10}$ values are observed in Central Europe, particularly in The Netherlands and west Germany, south Poland, north Italy and in 
Table 2. Location and altitude of the AERONET stations with data in 2000 and/or 2001.

\begin{tabular}{llllll}
\hline Code & Country & Station name & Lat./ ${ }^{\circ} \mathrm{N}$ & Lon./ ${ }^{\circ} \mathrm{E}$ & Alt./m \\
\hline AVI & France & Avignon & 43.93 & 4.88 & 32 \\
BIA & France & Biarritz & 43.48 & -1.55 & 0 \\
BOR & France & Bordeaux & 44.78 & 0.58 & 40 \\
BUC & Romania & Bucarest & 44.45 & 26.52 & 44 \\
CLE & France & Clermont Ferrand & 45.76 & 2.96 & 1464 \\
CRE & France & Creteil & 48.79 & 2.44 & 57 \\
GOT & Sweden & Gotland & 57.92 & 18.95 & 10 \\
HAM & Germany & Hamburg & 53.57 & 9.97 & 105 \\
HEL & Germany & Helgoland & 54.18 & 7.88 & 33 \\
KIS & Moldova & Kishinev & 47.0 & 28.82 & 205 \\
LEI & Germany & Leipzig & 51.35 & 12.43 & 125 \\
LIL & France & Lille & 50.62 & 3.15 & 60 \\
MOS & Russia & Moscow & 55.7 & 37.52 & 192 \\
NOR & Sweden & Norrkoeping & 58.58 & 16.15 & 0 \\
OOS & Belgium & Oostende & 51.22 & 2.92 & 23 \\
TOU & France & Toulouse & 43.58 & 1.37 & 150 \\
VEN & Italy & Venice & 45.32 & 12.5 & 10 \\
VIN & France & Vinon & 43.72 & 5.77 & 304 \\
\hline
\end{tabular}

\section{Annual mean PM10 in Europe}

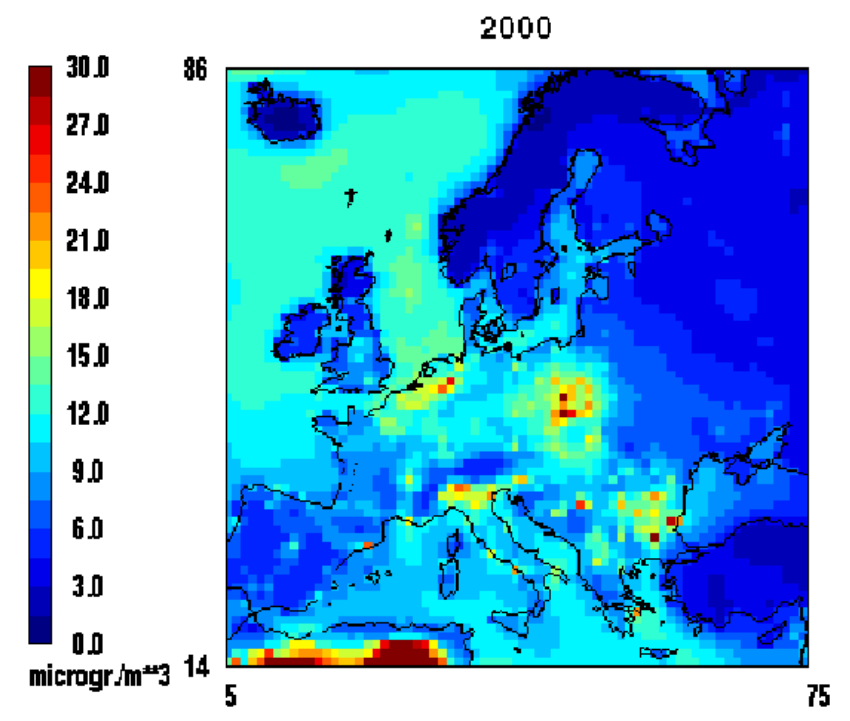

Fig. 2. Modelled $\mathrm{PM}_{10}$ values at ground level in Europe in 2000 for a $54 \times 54 \mathrm{~km}^{2}$ grid. Boundary effects are excluded from the figure.

Romania and Bulgaria. The distribution is dominated by secondary inorganic aerosols, namely sulfate, nitrate and ammonium. The high $\mathrm{PM}_{10}$ values over the North Sea and the east Atlantic are due to sea salt aerosol. The Iberian Peninsula, large parts of Great Britain, Scandinavia, and Russia show the lowest aerosol load. Very high values in North Africa are caused by Saharan dust. The modelled $\mathrm{PM}_{10}$ distribution for 2001 (not shown here) is very similar to that for 2000 .
To compare the modelled total aerosol mass with the measurements, only the model results in the lowest model layer are considered. Aerosol water is not taken into account in this step because it has already been shown that the modelled dry aerosol mass is more representative for the conditions of $50 \%$ relative humidity under which the aerosol filters are weighed. The modelled wet aerosol mass can be a factor of 7-10 higher than the dry mass in winter months (Matthias et al., 2008). Then, the total dry aerosol mass is averaged over the sampling period which is usually from 06:00 UTC to 06:00 UTC. Depending on the actual size distribution, this might include also small contributions from particles larger than $10 \mu \mathrm{m}$, but this has been neglected here. A time series is constructed considering all days when measurements are available, typically this covers more than 330 days per year. Examples for two selected stations are given in Fig. 3 and 4. From this time series basic statistical parameters are calculated, the same has been done for the measurements for the comparison. In Table 3 the mean values, the relative standard deviation over the time series, the skewness of the distribution and the correlation coefficient are presented for 2000 and 2001. Additionally, the geometric mean and the geometric standard deviation are given. They are more appropriate to describe "average" properties of the aerosol mass concentration, because the distribution function of the daily mean $\mathrm{PM}_{10}$ values is close to a log-normal distribution. This will be shown later in this paper. Nevertheless, the discussion of the results concentrates on the arithmetic means, because these values can better be compared to other results given in the literature, where arithmetic means are most frequently used. 
Table 3. Statistical measures of the aerosol mass density at ground level in the model at $54 \times 54 \mathrm{~km}^{2}$ resolution and measured at selected EMEP sites in 2000 and 2001. $\mathrm{PM}_{10}$ values are given in $\mu \mathrm{g} / \mathrm{m}^{3}$.

\begin{tabular}{llllllllllllll}
\hline \multicolumn{1}{c}{ Aerosol mass density at ground level 2000 } \\
\hline Station & \multicolumn{1}{c}{ mean } & bias & \multicolumn{2}{c}{ rel. stdv. } & \multicolumn{2}{c}{ skewness } & \multicolumn{2}{c}{ geom. mean } & \multicolumn{2}{c}{ geom. stdv. } & correlation \\
& meas. & model & & meas. & model & meas. & model & meas. & model & meas. & model & \\
\hline AT02 & 27.3 & 9.7 & -17.6 & 0.56 & 0.50 & 1.33 & 1.10 & 23.6 & 8.6 & 1.73 & 1.65 & 0.49 \\
CH02 & 19.8 & 8.0 & -11.8 & 0.62 & 0.57 & 1.50 & 1.20 & 16.5 & 6.7 & 1.85 & 1.90 & 0.36 \\
CH03 & 17.9 & 10.1 & -7.8 & 0.56 & 0.50 & 1.46 & 1.09 & 15.5 & 8.8 & 1.73 & 1.75 & 0.40 \\
DE01 & 20.5 & 11.7 & -8.8 & 0.46 & 0.61 & 1.13 & 1.18 & 18.5 & 9.8 & 1.57 & 1.88 & 0.57 \\
DE02 & 17.3 & 11.4 & -5.9 & 0.55 & 0.60 & 2.14 & 1.56 & 15.3 & 9.6 & 1.62 & 1.83 & 0.43 \\
DE04 & 14.8 & 11.4 & -3.4 & 0.48 & 0.54 & 1.00 & 1.51 & 13.3 & 9.8 & 1.62 & 1.77 & 0.47 \\
DE07 & 17.4 & 9.9 & -7.5 & 0.58 & 0.66 & 1.52 & 1.16 & 14.9 & 8.0 & 1.75 & 1.96 & 0.52 \\
DE09 & 19.6 & 10.5 & -9.1 & 0.53 & 0.57 & 1.48 & 0.98 & 17.3 & 8.1 & 1.65 & 1.80 & 0.59 \\
\hline
\end{tabular}

Aerosol mass density at ground level 2001

\begin{tabular}{lllllllllllll}
\hline Station & \multicolumn{2}{c}{ mean } & bias & \multicolumn{2}{c}{ rel. stdv. } & \multicolumn{2}{c}{ skewness } & \multicolumn{2}{c}{ geom. mean } & \multicolumn{2}{c}{ geom. stdv. } & correlation \\
& meas. & model & & meas. & model & meas. & model & meas. & model & meas. & model & \\
\hline AT02 & 26.1 & 9.9 & -16.2 & 0.61 & 0.51 & 1.31 & 0.92 & 22.1 & 8.7 & 1.80 & 1.68 & 0.35 \\
CH02 & 19.3 & 8.1 & -11.2 & 0.61 & 0.67 & 1.27 & 1.57 & 16.2 & 6.4 & 1.83 & 2.12 & 0.40 \\
CH03 & 18.1 & 10.0 & -8.1 & 0.62 & 0.57 & 1.66 & 1.23 & 15.2 & 8.3 & 1.79 & 1.92 & 0.49 \\
DE01 & 20.1 & 10.6 & -9.5 & 0.61 & 0.61 & 1.97 & 1.40 & 17.4 & 8.9 & 1.69 & 1.80 & 0.56 \\
DE02 & 16.3 & 11.4 & -4.9 & 0.73 & 0.64 & 3.77 & 1.72 & 13.7 & 9.5 & 1.75 & 1.84 & 0.63 \\
DE04 & 15.2 & 11.1 & -4.1 & 0.53 & 0.56 & 1.13 & 1.01 & 13.2 & 9.3 & 1.73 & 1.88 & 0.68 \\
DE07 & 15.6 & 9.9 & -5.7 & 0.79 & 0.76 & 2.54 & 1.67 & 12.5 & 7.6 & 1.92 & 2.07 & 0.69 \\
DE09 & 16.8 & 9.9 & -6.9 & 0.74 & 0.67 & 2.81 & 1.51 & 13.9 & 8.1 & 1.81 & 1.91 & 0.64 \\
\hline
\end{tabular}

At all stations the model mean concentrations are significantly lower than the measured values. The deviations range from 23\% at DE04 in 2000 to more than $60 \%$ at AT02 in 2000. Despite these significant discrepancies, the time series show correlation coefficients between 0.35 and 0.69. Low values of the correlation coefficient are caused by the fact that the model doesn't capture some of the higher $\mathrm{PM}_{10}$ measurements, e.g. at DE07 in summer 2000 (Fig. 3) and at CH02 in January/February 2000 and 2001 but also in the summer of both years (Fig. 4). Better agreement is achieved in spring and fall 2001 at DE07. The results are similar to those reported by Kahnert and Tarrason (2004) for simulations with the EMEP model. Compared to results for $\mathrm{PM}_{2.5}$ in the United States (Boylan and Russell, 2006; Mathur et al., 2008) that show good agreement for the mean values (mean bias less than $10 \%$ ), these are quite significant underestimations. At continental sites the modelled $\mathrm{PM}_{2.5}$ accounts for approx. $90 \%$ of the total aerosol mass. This is higher than measured values that show a typical $\mathrm{PM}_{2.5} / \mathrm{PM}_{10}$ ratio of about 0.7 (Putaud et al., 2004). Therefore a comparison of the $\mathrm{PM}_{2.5}$ fraction to measurements, if they would be available, would certainly yield lower deviations than for $\mathrm{PM}_{10}$.

The modelled time series show relative standard deviations similar to the measurements and the probability distribution functions of both, the measured and the modelled values, are
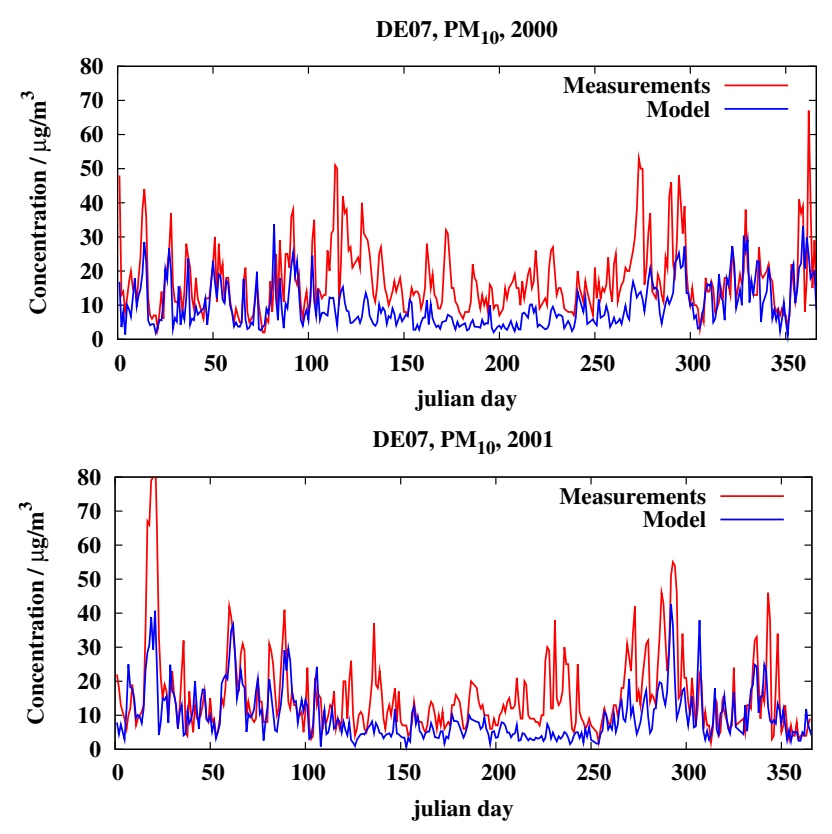

Fig. 3. Comparison of modelled (at $54 \times 54 \mathrm{~km}^{2}$ ) and measured $\mathrm{PM}_{10}$ values in 2000 and 2001 at Neuglobsow/Germany. 
Table 4. Statistical measures of the $\mathrm{PM}_{10}$ probability distribution function at stations where data from 2000 and 2001 was available. Results of a test for a log-normal distribution on the 95(\%) significance level ( $\chi^{2}$-test and KS-test, see text). Measured (mea.), modelled (mod.) and threshold (thr.) values are given. $\mathrm{PM}_{10}$ values are in $\mu \mathrm{g} / \mathrm{m}^{3}$. Bold numbers denote the test criteria were not met.

\begin{tabular}{llllllllllll}
\hline \multirow{2}{*}{ Station } & \multicolumn{2}{c}{ median } & \multicolumn{2}{c}{ s } & \multicolumn{3}{c}{$\chi^{2}$} & \multicolumn{3}{c}{ KS } & \multicolumn{2}{c}{ N } \\
& mea. & mod. & mea. & mod. & mea. & mod. & thr. & mea. & mod. & thr. & \\
\hline AT02 & 22.7 & 8.6 & 0.58 & 0.52 & $\mathbf{1 4 . 4}$ & 10.7 & 14.07 & 0.039 & 0.017 & 0.051 & 713 \\
CH02 & 16.3 & 6.5 & 0.61 & 0.70 & $\mathbf{1 5 . 1}$ & $\mathbf{4 2 . 8}$ & 14.07 & 0.034 & 0.048 & 0.051 & 719 \\
CH03 & 15.3 & 8.6 & 0.57 & 0.60 & 5.8 & $\mathbf{4 2 . 8}$ & 14.07 & 0.020 & 0.045 & 0.050 & 729 \\
DE01 & 17.8 & 9.3 & 0.50 & 0.61 & 13.0 & 8.6 & 14.07 & 0.025 & 0.022 & 0.052 & 680 \\
DE02 & 14.4 & 9.6 & 0.53 & 0.61 & 13.9 & 10.3 & 14.07 & 0.024 & 0.014 & 0.051 & 706 \\
DE04 & 13.2 & 9.5 & 0.52 & 0.62 & 8.9 & $\mathbf{3 9 . 6}$ & 14.07 & 0.019 & 0.047 & 0.051 & 717 \\
DE07 & 13.5 & 7.8 & 0.62 & 0.70 & 9.7 & 14.7 & 14.07 & 0.033 & 0.041 & 0.051 & 706 \\
DE09 & 15.4 & 8.4 & 0.56 & 0.62 & 8.9 & 9.6 & 14.07 & 0.020 & 0.020 & 0.051 & 705 \\
NO01 & 4.7 & 3.6 & 0.87 & 0.55 & $\mathbf{1 6 . 5}$ & $\mathbf{3 1 . 8}$ & 14.07 & $\mathbf{0 . 0 6 0}$ & $\mathbf{0 . 0 5 4}$ & 0.052 & 696 \\
\hline
\end{tabular}
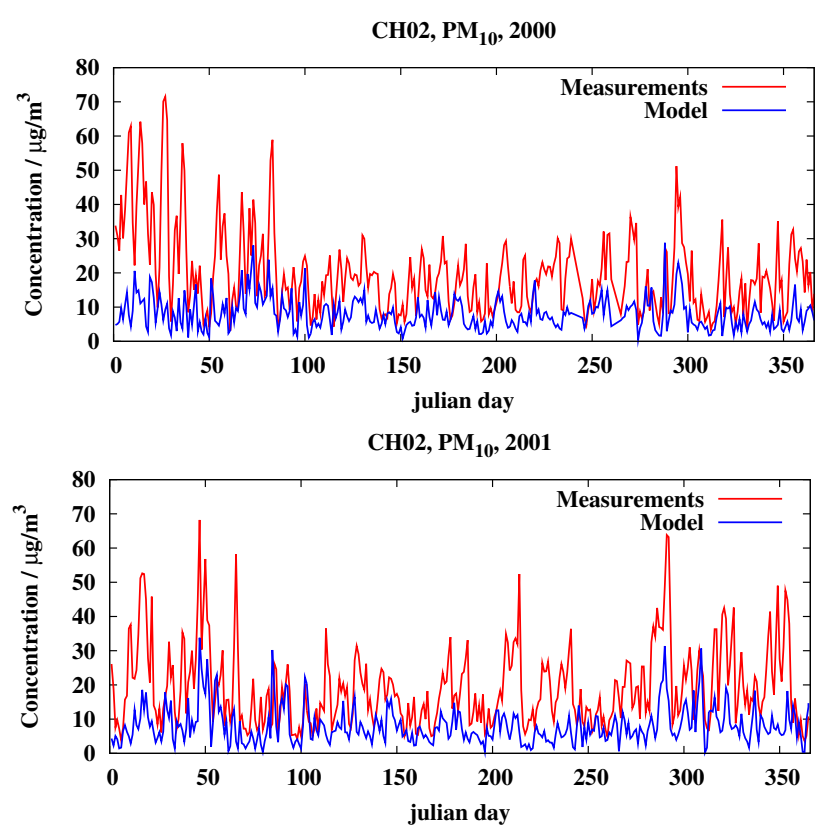

Fig. 4. Comparison of modelled (at $54 \times 54 \mathrm{~km}^{2}$ ) and measured $\mathrm{PM}_{10}$ values in 2000 and 2001 at Payerne/Switzerland.

asymmetric with values for the skewness between 1 and 2. In general, the skewness is somewhat higher for the measured values pointing to the fact that very high values are insufficiently captured by the model.

It is known that measured aerosol optical depth values follow a log-normal distribution (O'Neill et al., 2000; Matthias and Bösenberg, 2002; Behnert et al., 2007) and it is selfevident to assume that the mass densities follow such a distribution function as well. Two statistical tests were applied to the data-sets, the $\chi^{2}$-test and the Kolmogoroff-Smirnowtest (KS-test). The $\chi^{2}$-test looks for the quadratic deviation of the measured (or modelled) distribution from an ideal lognormal distribution derived from the statistical parameters of the data set. The KS-test determines the maximum absolute deviation from the ideal distribution. Both tests were appplied with threshold values on the $95 \%$ confidence interval. These threshold values depend on the number of classes that were chosen for the probability distribution function and on the total number of data points. Here, 9 classes were taken in a typical range between 3 and $60 \mu \mathrm{g} / \mathrm{m}^{3}$ for the measurements and between 1.5 and $30 \mu \mathrm{g} / \mathrm{m}^{3}$ for the modelled values. These values were adjusted from case to case to assure a minimum value of 5 elements per size class. The width of the classes increased exponentially with the $\mathrm{PM}_{10}$ values to account for their asymmetric distribution.

Table 4 shows the statistical measures of the $\mathrm{PM}_{10}$ probability distribution function at stations where data from 2000 and 2001 was available. The ratio of the median to the mean varies between 0.84 and 0.92 for the measurements, for the modelled values it is somewhat lower and ranges between 0.79 and 0.88 . This already indicates that the distribution function of the modelled values slightly differs from that of the measured values. The width of the distribution on logscale, represented by the standard deviation $s$, is at seven stations wider for the modelled values, at two stations it is wider for the measured values. However, the average difference is only 0.02 . Considering the statistical tests we can conclude that the measurements at six stations follow a log-normal distribution on the $95 \%$ significance level. At three stations (AT02, CH02, NO01) the $\chi^{2}$-test gives slightly higher values than the allowed value of 14.07 (for 9 classes and the 95\% significance level). On the other hand, the distribution function of the modelled values differs significantly from the log-normal distribution at four stations (CH02, CH03, DE04, NO01). At these stations also the KS-test shows values close to or above the limit value of approx. 0.051 (depending on the number of values). It is interesting to note that all these stations are at higher altitudes and in mountaineous terrain, although they are no clear mountain stations. 

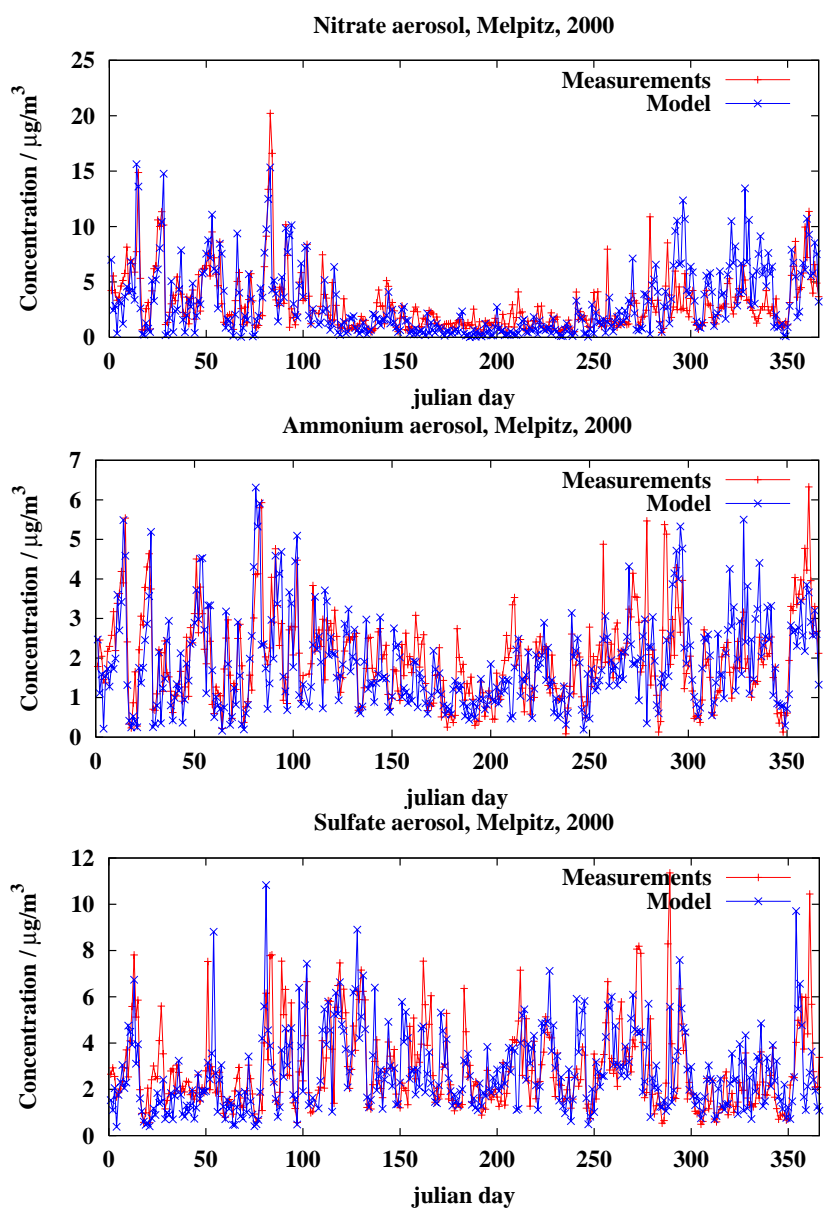

Fig. 5. Comparison of measured and modelled time series of nitrate, ammonium and sulfate aerosol at Melpitz/Germany (DE44)in 2000.

One reason for the discrepancies could be the coarse horizontal resolution of the model where mountains are not very well represented. Following this, one could expect better agreement of the measured and the modelled values on the $18 \times 18 \mathrm{~km}^{2}$ grid. All German stations (DE01, DE02, DE04, DE07 and DE09) and the Norwegian station (NO01) are within this nested grid. The statistical evaluation of the model results at the six stations revealed no large differences when compared to the results on the coarser grid. Such a finding was also reported by Tesche et al. (2006) for a $36 \mathrm{~km} / 12 \mathrm{~km}$ grid system in the eastern US. The bias between measurements and model results was reduced by 1.5 $2 \mu \mathrm{g} / \mathrm{m}^{3}$ at the coastal stations DE01 and DE09, and it was enhanced by $1-1.5 \mu \mathrm{g} / \mathrm{m}^{3}$ at the elevated station DE04. At the other stations, the differences were below $1 \mu \mathrm{g} / \mathrm{m}^{3}$. This result confirms the assumption that a better model resolution gives more reliable results at selected sites. At elevated stations the measured mean $\mathrm{PM}_{10}$ values are typically lower than in the surrounding area that is represented by the model with the coarse grid resolution. This leads to a better agreement with the model results if the model underestimates the
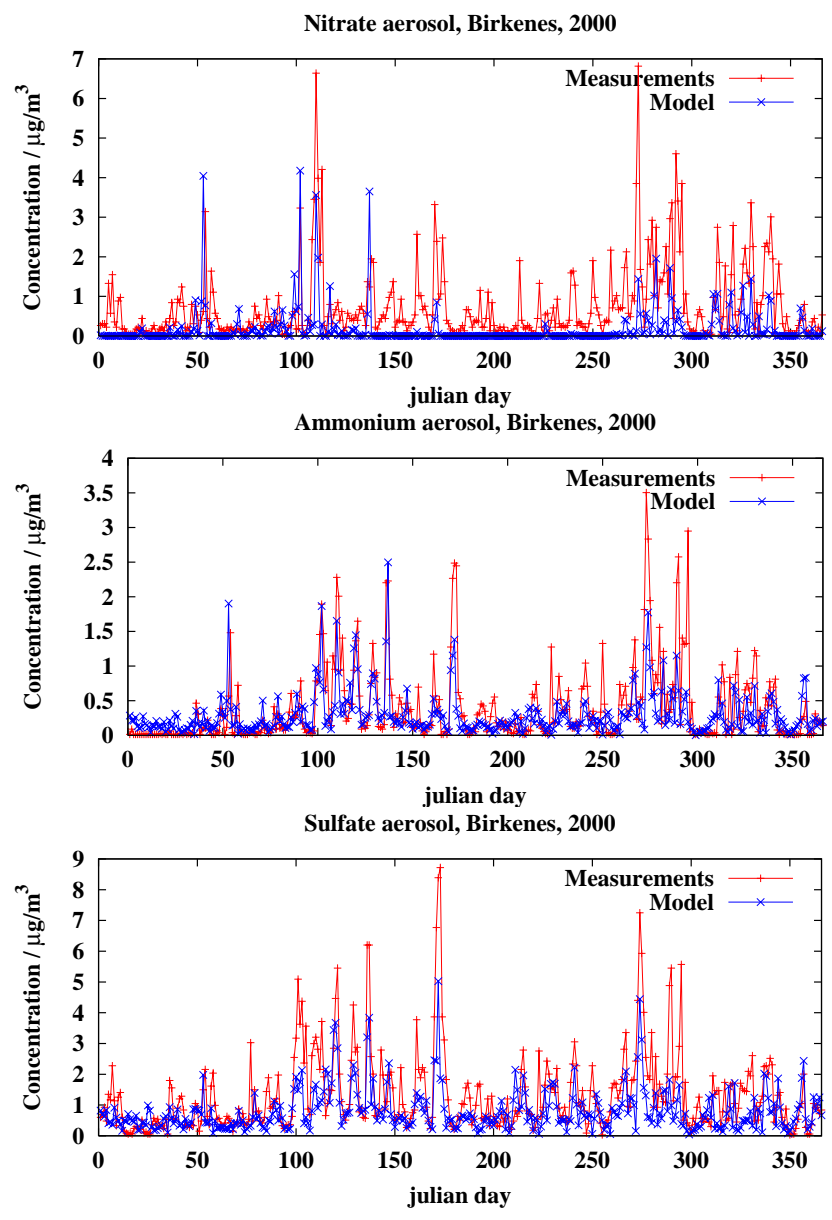

Fig. 6. Comparison of measured and modelled time series of nitrate, ammonium and sulfate aerosol at Birkenes/Norway (NO01) in 2000 .

total particle mass. In a finer grid resolution the lower values at elevated stations are better represented, but this leads to an enhanced bias. At coastal stations the finer grid captures the higher continental $\mathrm{PM}_{10}$ values compared to the open sea better and the bias between measurements and model results is reduced.

The better model performance in terms of reduced bias at some sites is not reflected in the other statistical parameters. The correlation coefficients were slightly lower at all stations in both years except for NO01 in 2000. Also the distribution functions were not closer to what was observed, only at DE01 and DE07 they could be represented by a lognormal distribution on the $95 \%$ significance level. At DE02 and DE09, where the test was passed on the coarse grid, this was not the case on the finer grid. Obviously, the reduced bias at some stations on the finer scale can be attributed to the better resolution of orography and land use, which cause systematic effects also on longer time scales. The statistical distribution of daily mean values is not largely affected by an improved spatial resolution. This might be due to the fact 
Table 5. Statistical measures of ammonium, nitrate, sulfate and sea salt at ground level in the model at $54 \times 54 \mathrm{~km}^{2}$ resolution and measured at Melpitz/Germany (DE44) on 364 days and Birkenes/Norway (NO01) on 366 days in 2000. Aerosol mass densities are given in $\mu \mathrm{g} / \mathrm{m}^{3}$.

\begin{tabular}{|c|c|c|c|c|c|c|c|c|c|c|c|c|}
\hline \multicolumn{13}{|c|}{ Melpitz (DE44) } \\
\hline \multirow[t]{2}{*}{ Component } & \multicolumn{2}{|c|}{ mean } & \multirow[t]{2}{*}{ bias } & \multicolumn{2}{|c|}{ rel. stdv. } & \multicolumn{2}{|c|}{ skewness } & \multicolumn{2}{|c|}{ geom. mean } & \multicolumn{2}{|c|}{ geom. stdv. } & \multirow[t]{2}{*}{ correlation } \\
\hline & meas. & model & & meas. & model & meas. & model & meas. & model & meas. & model & \\
\hline $\mathrm{NH}_{4}$ & 2.00 & 1.86 & -0.14 & 0.56 & 0.62 & 0.89 & 1.07 & 2.19 & 1.63 & 2.17 & 3.45 & 0.63 \\
\hline $\mathrm{NO}_{3}$ & 2.98 & 3.02 & 0.04 & 0.56 & 0.88 & 2.38 & 1.49 & 1.65 & 1.51 & 1.97 & 1.99 & 0.67 \\
\hline $\mathrm{SO}_{4}$ & 2.85 & 2.77 & -0.08 & 0.64 & 0.62 & 1.41 & 1.19 & 2.36 & 2.27 & 1.85 & 1.92 & 0.55 \\
\hline $\mathrm{Na}$ & 0.32 & 0.13 & -0.19 & 1.04 & 1.61 & 2.86 & 3.54 & 0.22 & 0.05 & 2.27 & 5.65 & 0.69 \\
\hline $\mathrm{Cl}$ & 0.43 & 0.18 & -0.25 & 0.90 & 1.61 & 2.20 & 3.54 & 0.32 & 0.06 & 2.08 & 5.65 & 0.48 \\
\hline \multicolumn{13}{|c|}{ Birkenes (NO01) } \\
\hline Station & \multicolumn{2}{|c|}{ mean } & bias & \multicolumn{2}{|c|}{ rel. stdv. } & \multicolumn{2}{|c|}{ skewness } & \multicolumn{2}{|c|}{ geom. mean } & \multicolumn{2}{|c|}{ geom. stdv. } & correlation \\
\hline & meas. & model & & meas. & model & meas. & model & meas. & model & meas. & model & \\
\hline $\mathrm{NO}_{3}$ & 0.74 & 0.18 & -0.56 & 1.28 & 2.78 & 2.74 & 5.29 & 0.39 & n.d. & 3.24 & n.d. & 0.49 \\
\hline $\mathrm{NH}_{4}$ & 0.39 & 0.29 & -0.10 & 1.41 & 1.08 & 2.42 & 3.03 & 0.14 & 0.19 & 4.94 & 2.56 & 0.67 \\
\hline $\mathrm{SO}_{4}$ & 1.33 & 0.93 & -0.40 & 0.99 & 0.75 & 2.38 & 2.15 & 0.86 & 0.73 & 2.71 & 2.06 & 0.69 \\
\hline $\mathrm{Na}$ & 0.45 & 0.64 & 0.19 & 1.14 & 0.91 & 2.12 & 1.86 & 0.24 & 0.43 & 3.62 & 2.61 & 0.65 \\
\hline $\mathrm{Cl}$ & 0.54 & 0.90 & 0.36 & 1.70 & 0.91 & 3.08 & 1.86 & 0.16 & 0.60 & 5.36 & 2.61 & 0.81 \\
\hline
\end{tabular}

that air masses typically travel over a few hundred kilometers per day, so on both grids daily means represent conditions influenced by several grid cells.

The fact that the variability of the aerosol mass is captured quite well suggests that the transport and deposition patterns which dominate the variability of the atmospheric aerosol are realistically modelled. Most important, many of the events with high aerosol load are captured quite well by the model, too, although the peak values might be underestimated. This can particularly be seen at the German stations (see Fig. 3 as an example) where the modelled winter values are in close agreement with the observations while in summer the modelled values are considerably lower than the measurements. At the stations in Switzerland (see Fig. 4) and Austria, $\mathrm{PM}_{10}$ is also underestimated in winter but the time series shows higher correlation coefficients in winter than in summer. This already indicates that the discrepancies between model and observations could be linked to photochemistry or to seasonally variable emissions, e.g. from biogenic sources and it is therefore useful to have a closer look at the chemical composition of the aerosol.

\subsection{Chemical composition}

Following the model results, the aerosol distribution over Europe is dominated by five chemical components in different modes: sulfate (in accumulation and coarse mode), nitrate, ammonium (both in accumulation mode), chloride and sodium (both in coarse mode). All five components were extracted from the model results for the comparison with the chemically speciated measurements at Birkenes (NO01) and
Melpitz (DE44). At these stations all components are available for 2000 which allows a more detailed investigation of the model performance. OC and EC were only available in 2001 at NO01. According to the model they should be of minor importance but measurements (e.g. Putaud et al., 2004) show that their mass fraction might be higher than the sum of the inorganic components. The importance of organic aerosol could be seen in a CMAQ model assessment by Mathur et al. (2008), too, but measurements are still sparse in Europe and a detailed investigation of the organic aerosol could not be done for this study.

For the comparison, the different size modes in the model were added to form the total mass of sulfate (all three modes), nitrate, ammonium (both with Aitken and accumulation mode), chloride and sodium (both with accumulation and coarse mode). The procedure to derive daily averages is the same as for total $\mathrm{PM}_{10}$, the different sampling period from 08:00 UTC to 08:00 UTC at DE44 was taken into account. The results are presented in Fig. 5 and the statistical parameters are given in Table 5. Compared to the results for $\mathrm{PM}_{10}$, the aerosol mass of the different species and their time series are captured very well at DE44. For sulfate, ammonium and nitrate, the annual mean of the modelled aerosol mass differs less than $10 \%$ from the measurements. The correlation coefficients range from 0.55 for sulfate to 0.67 for nitrate. Sodium and chloride are underestimated by the model by more than $50 \%$, however their contribution to the total aerosol mass is rather small. It is likely that the model underestimates the sea salt particles in the accumulation mode, which can be transported over much longer distances than the coarse particles. In the model, typically only a negligible part 
(less than $10^{-5}$ ) of the sea salt mass is in the accumulation mode while measurements show contributions of typically a few percent of the total mass, depending on the location (Putaud et al., 2004). Summed up, the chemically specified aerosol is $7.8 \%$ lower than the measurements with a correlation coefficient of $0.59 .83 \%$ of the modelled daily means agree with the measurements within a factor of 2 .

At NO01, the agreement of the model results with the measurements of the chemically speciated compounds is also much better than for $\mathrm{PM}_{10}$ (Fig. 6), but it is not as good as at DE44. Nitrate is significantly underestimated, particularly in summer. Only $24 \%$ of the measured nitrate is captured by the model, the correlation coefficient is 0.49 (Table 5). Ammonium and sulfate are underestimated by $25 \%$ and $30 \%$, respectively, however the temporal variability and therefore the transport patterns of these substances is captured quite well and this is represented by correlation coefficients of 0.67 and 0.68. Similar conclusions hold for sodium and chloride with correlation coeffcients of the annual time series of 0.65 and 0.81 . In contrast to the substances of anthropogenic origin, sea salt is overestimated by 40 to $60 \%$ at NO01. These compensating effects lead (however for the wrong reason) to a good agreement of the total measured chemically speciated aerosol mass with the model results (bias $-14.9 \%$, corr. coeff. $0.65,64 \%$ within a factor of 2 ).

It is interesting to have a closer look at the time series of the not specified aerosol mass at DE44 and NO01 (Fig. 7). This is the difference between $\mathrm{PM}_{10}$ and the five chemically specified components sulfate, nitrate, ammonium, sodium and chloride. At NO01, the largest deviations are observed between April and June, which might be caused by an enhanced contribution of primary particles of biogenic origin that are not included in the emission data and also not in CMAQ or by a massive secondary organic aerosol formation caused by enhanced biogenic emissions in spring that are incorrectly modelled. This feature can also be observed at DE44, although here significant deviations from the model results are observed in winter as well. Other recent publications of CMAQ model results in the US (Tesche et al., 2006; Boylan and Russell, 2006; McKeen et al., 2007; Mathur et al., 2008) also report underestimations of $\mathrm{PM}_{2.5}$ in summer, particularly nitrate and organic carbon (OC) contribute to this negative bias. Eder and $\mathrm{Yu}$ (2006) found in an annual CMAQ run for 2001 covering the whole US that OC was overestimated in the western part of the US except California and underestimated in the more industrialised regions in the eastern US.

It can be concluded that the model captures nitrate, sulfate and ammonium aerosol quite well while sea salt is underestimated at the more continental site DE44 and overestimated at NO01 which is closer to the coast. By far the largest deviations of the modelled aerosol mass to the measurements belongs to the particles that are chemically not specified in the measurements. Putaud et al. (2004) speculate that this unaccounted aerosol is partly aerosol water and partly or-
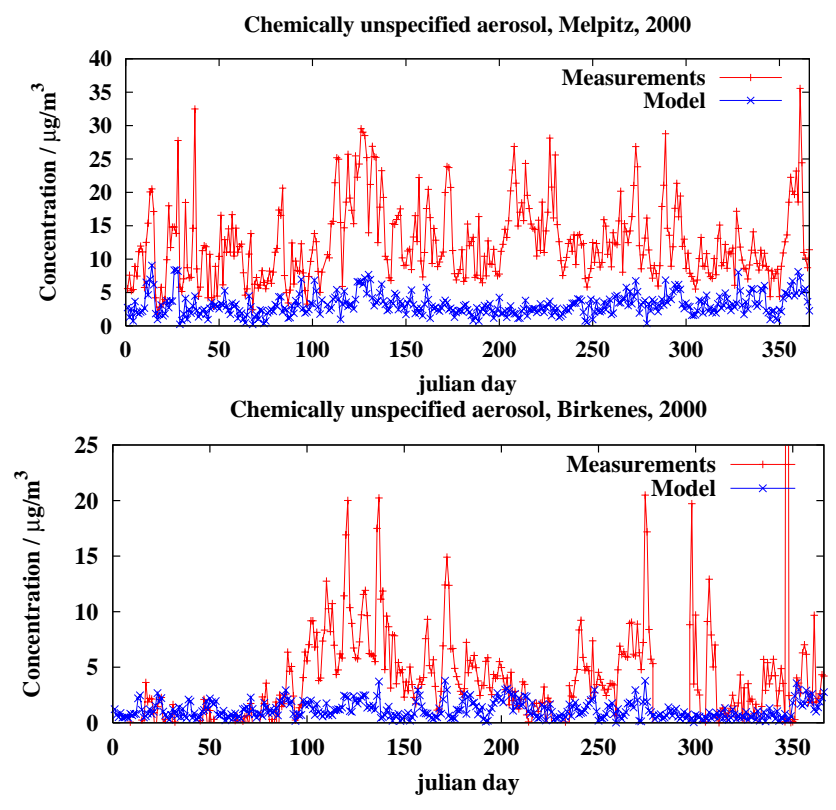

Fig. 7. Comparison of measured chemically unspecified aerosol mass density to the remaining modelled aerosol at Birkenes/Norway (NO01) and Melpitz/Germany (DE44) in 2000. The modelled aerosol mass consists of organic aerosol, elemental carbon, soil and unspeciated $\mathrm{PM}_{2.5}$ and $\mathrm{PM}_{\text {coarse. }}$.

ganic matter. The large fraction of $\mathrm{PM}_{2.5}$ in the total aerosol mass in the model results points also to the fact that coarse aerosols are underestimated. To get answers to this question it would be valuable to have more long term chemically speciated aerosol observations including organic carbon and some soil species.

The sum of organic aerosol and elemental carbon at NO01 in 2001 (February till June and October till December) was compared to the modelled values. It was found to be approx. a factor of 3 higher than the modelled values. Obviously, significant aerosol emission sources and formation processes, in particular of organic aerosols, are likely to be not yet correctly included in the model. This includes uncertainties in the amount of primary OC and EC emissions already mentioned in Sect. 2.2. An estimate showed that the total EC and $\mathrm{OC}$ emissions in the inventory that was used here are approximately a factor of 5 lower than recently reported by Kupiainen and Klimont (2007) for the year 1995. An increase of the OC and EC emissions by this factor would lead to about twice the organic aerosol concentrations if they were annually averaged over the entire domain. The large discrepancies in EC and OC emission inventories (see e.g. Bond et al., 2004; Cooke and Wilson, 1996) and the deficiencies in the modeling of organic aerosols have already been identified earlier and a lot of research is done to improve particularly the secondary organic aerosol formation in CTMs (e.g. Pun et al., 2003; Yin et al., 2004; Kanakidou et al., 2005; Fuzzi et al., 2006). 
Table 6. Comparison of ammonium aerosol measurements with model derived values at $54 \times 54 \mathrm{~km}^{2}$ resolution in 2000 and 2001 . Aerosol mass densities are given in $\mu \mathrm{g} / \mathrm{m}^{3}$, n.d.: not determined.

\begin{tabular}{|c|c|c|c|c|c|c|c|c|c|c|c|c|c|}
\hline \multicolumn{14}{|c|}{ Ammonium mass density at ground level 2000} \\
\hline \multirow[t]{2}{*}{ Station } & \multicolumn{2}{|c|}{ mean } & \multirow[t]{2}{*}{ bias } & \multicolumn{2}{|c|}{ rel. stdv. } & \multicolumn{2}{|c|}{ skewness } & \multicolumn{2}{|c|}{ geom. mean } & \multicolumn{2}{|c|}{ geom. stdv. } & \multirow[t]{2}{*}{ correlation } & \\
\hline & meas. & model & & meas. & model & meas. & model & meas. & model & meas. & model & & \\
\hline CZ03 & 1.32 & 1.97 & 0.650 & 0.81 & 0.58 & 2.97 & 1.19 & 1.04 & 1.66 & 1.97 & 1.82 & 0.38 & 366 \\
\hline HU02 & 1.90 & 1.94 & 0.041 & 0.66 & 0.59 & 1.06 & 1.57 & 1.39 & 1.66 & 2.77 & 1.75 & 0.59 & 349 \\
\hline IT01 & 2.06 & 1.43 & -0.631 & 0.58 & 0.93 & 1.41 & 2.83 & 1.75 & 1.08 & 1.81 & 2.05 & 0.56 & 345 \\
\hline IT04 & 4.36 & 1.64 & -2.724 & 0.91 & 0.85 & 1.88 & 2.64 & 2.67 & 1.27 & 3.24 & 2.01 & 0.20 & 312 \\
\hline NL09 & 1.29 & 1.63 & 0.337 & 0.71 & 0.92 & 1.41 & 2.18 & 1.01 & 1.11 & 2.10 & 2.50 & 0.45 & 316 \\
\hline NO08 & 0.28 & 0.26 & -0.022 & 1.74 & 1.11 & 4.09 & 2.99 & 0.10 & 0.17 & 4.49 & 2.53 & 0.69 & 348 \\
\hline RU01 & 0.29 & 0.17 & -0.118 & 0.79 & 1.16 & 2.13 & 3.32 & 0.23 & 0.12 & 2.09 & 2.42 & 0.42 & 294 \\
\hline RU18 & 0.85 & 0.62 & -0.232 & 0.70 & 1.04 & 2.12 & 2.04 & 0.69 & 0.40 & 1.90 & 2.61 & 0.37 & 326 \\
\hline \multicolumn{14}{|c|}{ Ammonium mass density at ground level 2001} \\
\hline Station & \multicolumn{2}{|c|}{ mean } & bias & \multicolumn{2}{|c|}{ rel. stdv. } & \multicolumn{2}{|c|}{ skewness } & \multicolumn{2}{|c|}{ geom. mean } & \multicolumn{2}{|c|}{ geom. stdv. } & correlation & $\mathrm{N}$ \\
\hline & meas. & model & & meas. & model & meas. & model & meas. & model & meas. & model & & \\
\hline CZ03 & n.d. & n.d. & n.d. & n.d. & n.d. & n.d. & n.d. & n.d. & n.d. & n.d. & n.d. & n.d. & 0 \\
\hline HU02 & 1.94 & 1.82 & -0.11 & 0.79 & 0.66 & 1.79 & 1.36 & 1.47 & 1.48 & 2.15 & 1.92 & 0.65 & 348 \\
\hline IT01 & 1.88 & 1.32 & -0.56 & 0.51 & 0.83 & 1.34 & 1.99 & 1.65 & 1.00 & 1.68 & 2.06 & 0.16 & 346 \\
\hline IT04 & 2.82 & 1.49 & -1.32 & 1.21 & 0.81 & 3.34 & 2.34 & 1.50 & 1.16 & 3.71 & 2.00 & 0.30 & 224 \\
\hline NL09 & 1.59 & 1.50 & -0.09 & 0.76 & 0.99 & 1.73 & 1.96 & 1.22 & 0.91 & 2.10 & 2.97 & 0.50 & 327 \\
\hline NO08 & 0.35 & 0.33 & -0.02 & 1.40 & 1.06 & 2.16 & 3.42 & 0.13 & 0.21 & 4.56 & 2.71 & 0.34 & 358 \\
\hline RU01 & 0.35 & 0.19 & -0.16 & 0.77 & 1.05 & 1.38 & 2.80 & 0.26 & 0.13 & 2.43 & 2.58 & 0.43 & 328 \\
\hline RU18 & 0.85 & 0.67 & -0.18 & 0.65 & 1.23 & 1.60 & 2.51 & 0.71 & 0.39 & 1.84 & 2.78 & 0.35 & 297 \\
\hline
\end{tabular}

Sulfate, nitrate and ammonium were in addition measured at several EMEP stations in 2000 and 2001. Details about what was measured at which site can be derived from Table 1. Unfortunately, at none of these stations except at NO01 (that was already discussed) also $\mathrm{PM}_{10}$ was available. The results are summarized in Tables 6-8. Largest differences are observed in Italy, particularly at Ispra which is at the north side of the Po valley. Here nitrate, ammonium and sulfate are significantly underestimated, at all other stations the annual means of nitrate and ammonium are captured rather well. Sulfate is also underestimated in Germany and Denmark. The temporal evolution, reflected by the correlation coefficient is captured well at most stations for sulfate (correlation coeffcients between 0.4 and 0.7 ). The correlations are lower for ammonium and nitrate (about half of the stations are not better than 0.4). Ammonium is not captured very well in south Europe (IT04 and ES11) while nitrate shows particularly low correlations in remote regions (NO08 and RU01). Similar to CMAQ model results in the US, ammonium and nitrate are significantly underestimated in summer, but the agreement with the observations is much better in winter. Despite the diffculties to capture the IA correctly in some regions like the Po valley, the total amount of IA is on average only underestimated by $15-20 \%$ in most regions of Europe. Having in mind that natural sources of SIA precur- sors are not considered in the emissions this result is very satisfying. Discrepancies in modelled and measured $\mathrm{PM}_{10}$ are much higher than for IA only.

Differences between the years are often quite small in both, observations and model results. They are likely caused by the meteorological influence on the aerosol distribution, because the emissions were kept the same in the simulations of both years. The small changes in the observations between both years indicate that this approach is well justified. It is interesting to note that the statistical results of the comparisons at individual stations are similar in both years. Much larger differences are observed among the stations, pointing to the fact that the results of a comparison between modelled and measured aerosol concentrations highly depend on the choice of the measurement station.

\subsection{Aerosol optical depth}

The aerosol optical depth is derived from the model results using a simple approach described by Malm et al. (1994). This emperical formula is known as reconstructed extinction and it is already used in CMAQ to derive extinction values in the lowest model layer. It is valid for the mid-visible spectrum around $500 \mathrm{~nm}$ wavelength. The extinction coefficient 
Table 7. Comparison of nitrate aerosol measurements with model derived values at $54 \times 54 \mathrm{~km}^{2}$ resolution in 2000 and 2001 . Aerosol mass densities are given in $\mu \mathrm{g} / \mathrm{m}^{3}$, n.d.: not determined.

\begin{tabular}{lccccccccccccc}
\hline \multicolumn{10}{c}{ Nitrate mass density at ground level 2000} \\
\hline Station & \multicolumn{1}{c}{ mean } & bias & \multicolumn{2}{c}{ rel. stdv. } & \multicolumn{2}{c}{ skewness } & \multicolumn{2}{c}{ geom. mean } & \multicolumn{2}{c}{ geom. stdv. } & correlation & N \\
& meas. & model & & meas. & model & meas. & model & meas. & model & meas. & model & \\
\hline CZ03 & 2.78 & 3.22 & 0.44 & 0.73 & 1.02 & 1.53 & 1.59 & 1.98 & 1.70 & 2.65 & 3.74 & 0.38 & 366 \\
HU02 & 2.76 & 2.44 & -0.32 & 0.95 & 1.31 & 1.81 & 1.79 & 1.78 & 0.64 & 2.81 & 7.88 & 0.59 & 349 \\
IT01 & 3.62 & 2.03 & -1.59 & 0.73 & 1.71 & 1.51 & 3.10 & 2.79 & 0.29 & 2.13 & 40.81 & 0.56 & 345 \\
IT04 & 10.00 & 2.38 & -7.62 & 1.06 & 1.61 & 2.36 & 3.59 & 6.28 & 0.72 & 2.70 & 8.31 & 0.20 & 314 \\
NL09 & 2.78 & 2.83 & 0.05 & 0.74 & 1.19 & 1.40 & 2.62 & 2.10 & 1.34 & 2.30 & 4.16 & 0.45 & 314 \\
NO08 & 0.51 & 0.15 & -0.35 & 1.34 & 2.39 & 4.79 & 5.40 & 0.31 & 0.03 & 2.68 & 8.53 & 0.69 & 349 \\
RU01 & 0.21 & 0.07 & -0.14 & 0.92 & 4.06 & 2.85 & 7.05 & 0.16 & n.d. & 2.16 & n.d. & 0.42 & 294 \\
RU18 & 0.67 & 0.69 & 0.02 & 0.87 & 2.09 & 1.68 & 2.83 & 0.48 & n.d. & 2.33 & n.d. & 0.37 & 325 \\
\hline
\end{tabular}

Nitrate mass density at ground level 2001

\begin{tabular}{lccccccccccccc}
\hline Station & \multicolumn{2}{c}{ mean } & bias & \multicolumn{2}{c}{ rel. stdv. } & \multicolumn{2}{c}{ skewness } & \multicolumn{2}{c}{ geom. mean } & \multicolumn{2}{c}{ geom. stdv. } & correlation & N \\
& meas. & model & & meas. & model & meas. & model & meas. & model & meas. & model & \\
\hline CZ03 & n.d. & n.d. & n.d. & n.d. & n.d. & n.d. & n.d. & n.d. & n.d. & n.d. & n.d. & n.d. & 0 \\
HU02 & 2.71 & 2.52 & -0.19 & 1.01 & 1.22 & 2.22 & 1.60 & 1.83 & 0.69 & 2.37 & 7.91 & 0.80 & 348 \\
IT01 & 3.17 & 1.73 & -1.43 & 0.54 & 1.52 & 1.21 & 2.92 & 2.75 & 0.36 & 1.72 & 17.67 & 0.60 & 346 \\
IT04 & 5.52 & 2.17 & -3.35 & 1.14 & 1.38 & 1.84 & 2.71 & 2.64 & 0.71 & 3.85 & 6.39 & 0.45 & 227 \\
NL09 & 3.28 & 2.57 & -0.71 & 0.83 & 1.25 & 1.60 & 1.97 & 2.23 & 0.97 & 2.71 & 5.68 & 0.72 & 325 \\
NO08 & 0.70 & 0.30 & -0.40 & 1.55 & 2.43 & 4.11 & 5.81 & 0.37 & 0.04 & 2.96 & 15.63 & 0.30 & 344 \\
RU01 & 0.22 & 0.09 & -0.14 & 1.12 & 3.05 & 4.54 & 4.51 & 0.16 & 0.00 & 2.31 & n.d. & 0.40 & 328 \\
RU18 & 0.78 & 0.78 & -0.00 & 1.16 & 2.12 & 3.23 & 2.81 & 0.51 & 0.00 & 2.43 & n.d. & 0.43 & 297 \\
\hline
\end{tabular}

depends on aerosol mass and humidity in the following way:

$\alpha_{\text {ext }}=0.003 f(\mathrm{RH})\left(m_{\mathrm{NH}_{4}}+m_{\mathrm{NO}_{3}}+m_{\mathrm{SO}_{4}}\right)+$

$0.004 m_{\mathrm{OM}}+0.01 m_{\mathrm{EC}}+$

$0.001 m_{\mathrm{PM} 2.5_{\text {oth }}}+0.0006 m_{\mathrm{PM}_{\text {coarse }}}$,

where $m_{X}$ denotes the mass $m$ of species $X$ which are ammonium $\left(\mathrm{NH}_{4}\right)$, nitrate $\left(\mathrm{NO}_{3}\right)$, sulfate $\left(\mathrm{SO}_{4}\right)$, organic matter (OM), elemental carbon (EC), other accumulation mode aerosols (PM2.5 oth $)$ and all coarse mode aerosol ( $\left.\mathrm{PM}_{\text {coarse }}\right)$. The relative humidity correction $f(\mathrm{RH})$ is described by Malm et al. (1994) and it is provided in look-up tables. It varies between 1 (at low $\mathrm{RH}$ ) and 21 (at $\mathrm{RH}=99 \%$ ). All coefficients in Eq. (1) are given in $\mathrm{m}^{2} / \mathrm{mg}$. The extinction is calculated from the aerosol mass for all model layers and then vertically integrated to give the aerosol optical depth. The results for 11 stations in 2000 and 16 stations in 2001 are summarized in Table 9. The aerosol optical depth is underestimated at almost all stations, the range of deviations is 20-70\%. Only at CLE, a mountain station at $1464 \mathrm{~m}$ a.s.1., the model overestimates the AOD because the model results include contributions from lower regions in the $54 \times 54 \mathrm{~km}^{2}$ grid cell. The lower AOD values in the model are in agreement with the underestimation of the aerosol mass which has already been described. The relative standard deviation of the timeseries and the skewness of the modelled and measured distribution function are again in good agreement which means that the model captures the variability quite well although the total mass is underestimated. The correlation coefficients are somewhat lower as for the aerosol mass. This can be explained by the fact that the optical depth cannot be only represented by the aerosol mass. It depends on the actual size and shape of the particles and on their size distribution in several layers. For the hygroscopic particles, which is the largest part in Europe, this is highly dependent on the relative humidity. A few percent difference in humidity at high relative humidities can lead to very large discrepancies in the AOD values which then results in poor correlation coefficients caused by a few outliers in the time series.

To get further insight in the reasons for the discrepancies between the modelled and the measured AOD values, the average annual cycle of the AOD was calculated for the stations with the highest number of measurements in the years 2000 and 2001. At AVI, KIS, LIL and VEN, more than 250 measurement days from both years could be used for the statistics. To take more remote areas into account the data from GOT (121 measurement days) was additionally evaluated. Figure 8 shows the data points and an annual cycle that is derived as 6 weeks gliding average from all measurements and the corresponding model results for AVI and LIL. At LIL, the annual cycle of the AOD is represented in the model results, although with lower amplitude. This was also recognized at KIS and GOT (not shown). The model 
Table 8. Comparison of sulfate aerosol measurements with model derived values at $54 \times 54 \mathrm{~km}^{2}$ resolution in 2000 and 2001 . Aerosol mass densities are given in $\mu \mathrm{g} / \mathrm{m}^{3}$.

\begin{tabular}{|c|c|c|c|c|c|c|c|c|c|c|c|c|c|}
\hline \multicolumn{14}{|c|}{ Sulfate mass density at ground level 2000} \\
\hline \multirow[t]{2}{*}{ Station } & \multicolumn{2}{|c|}{ mean } & \multirow[t]{2}{*}{ bias } & \multicolumn{2}{|c|}{ rel. stdv. } & \multicolumn{2}{|c|}{ skewness } & \multicolumn{2}{|c|}{ geom. mean } & \multicolumn{2}{|c|}{ geom. stdv. } & \multirow[t]{2}{*}{ correlation } & \multirow[t]{2}{*}{$\mathrm{N}$} \\
\hline & meas. & model & & meas. & model & meas. & model & meas. & model & meas. & model & & \\
\hline AT02 & 3.07 & 2.62 & -0.45 & 0.61 & 0.57 & 0.90 & 1.62 & 2.49 & 2.25 & 2.01 & 1.78 & 0.61 & 320 \\
\hline $\mathrm{CH} 02$ & 1.78 & 1.87 & 0.09 & 0.64 & 0.58 & 1.30 & 1.39 & 1.45 & 1.58 & 1.97 & 1.85 & 0.28 & 362 \\
\hline DE07 & 3.20 & 2.33 & -0.87 & 0.77 & 0.69 & 1.84 & 1.37 & 2.50 & 1.84 & 2.03 & 2.05 & 0.55 & 338 \\
\hline DE09 & 3.15 & 2.06 & -1.09 & 0.67 & 0.67 & 1.93 & 1.61 & 2.63 & 1.68 & 1.80 & 1.92 & 0.65 & 366 \\
\hline DK03 & 2.43 & 1.51 & -0.92 & 0.59 & 0.71 & 1.48 & 1.39 & 2.08 & 1.18 & 1.75 & 2.05 & 0.65 & 327 \\
\hline DK05 & 2.99 & 2.01 & -0.98 & 0.56 & 0.67 & 1.13 & 1.67 & 2.56 & 1.64 & 1.79 & 1.92 & 0.64 & 360 \\
\hline DK08 & 2.46 & 1.70 & -0.76 & 0.60 & 0.62 & 1.59 & 1.17 & 2.10 & 1.39 & 1.75 & 1.97 & 0.66 & 355 \\
\hline ES11 & 2.23 & 2.00 & -0.23 & 0.68 & 0.41 & 2.01 & 0.85 & 1.88 & 1.84 & 1.82 & 1.51 & 0.21 & 351 \\
\hline FI22 & 1.20 & 0.75 & -0.45 & 0.80 & 0.84 & 1.77 & 3.16 & 0.88 & 0.57 & 2.33 & 2.17 & 0.64 & 364 \\
\hline FR09 & 2.40 & 3.02 & 0.62 & 0.62 & 0.64 & 1.86 & 2.01 & 2.05 & 2.54 & 1.74 & 1.80 & 0.47 & 342 \\
\hline GB07 & 2.35 & 2.24 & -0.11 & 0.74 & 0.67 & 1.40 & 1.97 & 1.81 & 1.86 & 2.10 & 1.82 & 0.49 & 345 \\
\hline GB14 & 1.81 & 2.11 & 0.30 & 0.73 & 0.75 & 2.43 & 2.07 & 1.49 & 1.66 & 1.83 & 2.03 & 0.42 & 358 \\
\hline HU02 & 4.95 & 3.72 & -1.23 & 0.63 & 0.56 & 1.40 & 1.26 & 3.83 & 3.19 & 2.50 & 1.77 & 0.64 & 349 \\
\hline IT01 & 3.24 & 2.75 & -0.49 & 0.53 & 0.59 & 0.92 & 2.31 & 2.80 & 2.40 & 1.76 & 1.67 & 0.48 & 345 \\
\hline IT04 & 5.62 & 2.80 & -2.82 & 0.77 & 0.57 & 1.05 & 1.27 & 3.88 & 2.40 & 2.63 & 1.76 & 0.37 & 314 \\
\hline NL09 & 1.85 & 2.41 & 0.56 & 0.69 & 0.69 & 1.64 & 2.46 & 1.48 & 2.00 & 2.00 & 1.82 & 0.28 & 316 \\
\hline NO08 & 1.04 & 0.71 & -0.33 & 1.15 & 1.01 & 3.58 & 3.40 & 0.67 & 0.50 & 2.70 & 2.40 & 0.72 & 349 \\
\hline RU01 & 1.05 & 0.63 & -0.42 & 1.00 & 0.74 & 2.51 & 1.96 & 0.71 & 0.48 & 2.53 & 2.23 & 0.44 & 294 \\
\hline RU18 & 1.69 & 1.99 & 0.30 & 0.79 & 0.66 & 2.17 & 1.48 & 1.32 & 1.63 & 2.03 & 1.90 & 0.44 & 326 \\
\hline SE02 & 2.16 & 1.38 & -0.78 & 1.01 & 0.68 & 6.79 & 1.54 & 1.59 & 1.11 & 2.37 & 1.99 & 0.54 & 361 \\
\hline \multicolumn{14}{|c|}{ Sulfate mass density at ground level 2001} \\
\hline Station & \multicolumn{2}{|c|}{ mean } & bias & \multicolumn{2}{|c|}{ rel. stdv. } & \multicolumn{2}{|c|}{ skewness } & \multicolumn{2}{|c|}{ geom. mean } & \multicolumn{2}{|c|}{ geom. stdv. } & correlation & \\
\hline & meas. & model & & meas. & model & meas. & model & meas. & model & meas. & model & & \\
\hline AT02 & 3.37 & 2.66 & -0.71 & 0.68 & 0.69 & 1.74 & 2.23 & 2.73 & 2.19 & 1.96 & 1.87 & 0.57 & 356 \\
\hline $\mathrm{CH} 02$ & 2.16 & 1.86 & -0.30 & 0.66 & 0.71 & 1.20 & 1.71 & 1.73 & 1.45 & 2.01 & 2.15 & 0.28 & 356 \\
\hline DE07 & 3.13 & 2.41 & -0.72 & 0.90 & 0.84 & 2.45 & 2.28 & 2.32 & 1.81 & 2.16 & 2.18 & 0.63 & 361 \\
\hline DE09 & 3.21 & 2.18 & -1.03 & 0.87 & 0.83 & 3.24 & 2.53 & 2.50 & 1.68 & 1.99 & 2.04 & 0.68 & 363 \\
\hline DK03 & 2.32 & 1.73 & -0.59 & 0.78 & 0.86 & 1.88 & 2.01 & 1.80 & 1.29 & 2.03 & 2.14 & 0.62 & 341 \\
\hline DK05 & 2.52 & 2.06 & -0.46 & 0.70 & 0.80 & 2.08 & 2.17 & 2.05 & 1.60 & 1.94 & 2.02 & 0.66 & 340 \\
\hline DK08 & 2.41 & 1.81 & -0.60 & 0.71 & 0.81 & 1.70 & 2.32 & 1.95 & 1.40 & 1.92 & 2.05 & 0.68 & 345 \\
\hline ES11 & 2.80 & 2.16 & -0.64 & 0.87 & 0.55 & 2.19 & 1.50 & 2.14 & 1.89 & 2.00 & 1.69 & 0.44 & 356 \\
\hline FI22 & 1.17 & 0.81 & -0.36 & 0.78 & 0.88 & 1.22 & 2.23 & 0.83 & 0.58 & 2.43 & 2.35 & 0.59 & 311 \\
\hline FR09 & 2.21 & 3.00 & 0.79 & 0.55 & 0.61 & 1.22 & 1.60 & 1.92 & 2.49 & 1.70 & 1.87 & 0.45 & 353 \\
\hline GB07 & 2.36 & 2.38 & 0.02 & 0.68 & 0.74 & 1.36 & 2.52 & 1.91 & 1.94 & 1.96 & 1.85 & 0.41 & 297 \\
\hline GB14 & 1.85 & 2.15 & 0.30 & 0.77 & 0.88 & 1.77 & 2.92 & 1.44 & 1.63 & 2.05 & 2.07 & 0.39 & 354 \\
\hline HU02 & 4.75 & 3.43 & -1.32 & 0.69 & 0.68 & 1.85 & 2.04 & 3.86 & 2.84 & 1.94 & 1.83 & 0.59 & 348 \\
\hline IT01 & 2.99 & 2.65 & -0.34 & 0.53 & 0.55 & 0.86 & 1.96 & 2.59 & 2.32 & 1.76 & 1.67 & 0.50 & 346 \\
\hline IT04 & 3.62 & 2.68 & -0.94 & 0.73 & 0.63 & 1.47 & 1.39 & 2.74 & 2.24 & 2.23 & 1.81 & 0.33 & 227 \\
\hline NL09 & 2.16 & 2.25 & 0.09 & 0.71 & 0.79 & 1.55 & 2.90 & 1.70 & 1.78 & 2.09 & 1.98 & 0.35 & 327 \\
\hline NO08 & 1.01 & 0.81 & -0.20 & 1.06 & 0.86 & 2.22 & 1.93 & 0.64 & 0.58 & 2.68 & 2.36 & 0.51 & 353 \\
\hline RU01 & 1.27 & 0.69 & -0.58 & 1.19 & 0.83 & 3.23 & 2.35 & 0.73 & 0.51 & 2.93 & 2.33 & 0.35 & 328 \\
\hline RU18 & 1.69 & 1.87 & 0.18 & 0.93 & 0.84 & 3.22 & 2.80 & 1.25 & 1.42 & 2.17 & 2.12 & 0.49 & 297 \\
\hline SE02 & 2.32 & 1.50 & -0.82 & 0.87 & 0.84 & 2.23 & 2.42 & 1.67 & 1.15 & 2.34 & 2.06 & 0.56 & 364 \\
\hline
\end{tabular}


Table 9. Statistical measures of the aerosol optical depth at a wavelength of $500 \mathrm{~nm}$ from AERONET measurements with model derived values at $54 \times 54 \mathrm{~km}^{2}$ resolution in 2000 and 2001 .

\begin{tabular}{|c|c|c|c|c|c|c|c|c|c|c|c|c|c|}
\hline \multicolumn{14}{|c|}{ Aerosol Optical Depth 2000} \\
\hline \multirow[t]{2}{*}{ Station } & \multicolumn{2}{|c|}{ mean } & \multirow[t]{2}{*}{ bias } & \multicolumn{2}{|c|}{ rel. stdv } & \multicolumn{2}{|c|}{ skewness } & \multicolumn{2}{|c|}{ geom. mean } & \multicolumn{2}{|c|}{ geom. stdv. } & \multirow[t]{2}{*}{ corr. } & \multirow[t]{2}{*}{$\mathrm{N}$} \\
\hline & meas. & model & & meas. & model & meas. & model & meas. & model & meas. & model & & \\
\hline AVI & 0.17 & 0.05 & -0.12 & 0.68 & 0.85 & 1.49 & 2.73 & 0.14 & 0.04 & 1.89 & 1.91 & 0.54 & 190 \\
\hline BUC & 0.20 & 0.11 & -0.09 & 0.47 & 0.69 & 0.82 & 0.87 & 0.18 & 0.08 & 1.69 & 2.17 & -0.10 & 35 \\
\hline CLE & 0.09 & 0.10 & 0.01 & 0.59 & 0.62 & 0.80 & 0.66 & 0.08 & 0.08 & 2.07 & 2.07 & 0.60 & 15 \\
\hline GOT & 0.12 & 0.06 & -0.06 & 0.88 & 0.89 & 1.96 & 3.02 & 0.09 & 0.05 & 2.17 & 1.86 & 0.85 & 37 \\
\hline HAM & 0.20 & 0.17 & -0.03 & 0.58 & 0.83 & 0.94 & 1.82 & 0.17 & 0.12 & 1.79 & 2.18 & 0.32 & 65 \\
\hline HEL & 0.19 & 0.14 & -0.05 & 0.74 & 0.84 & 2.02 & 1.30 & 0.16 & 0.09 & 1.79 & 2.60 & 0.49 & 43 \\
\hline LAM & 0.25 & 0.07 & -0.18 & 0.52 & 0.40 & 1.52 & 0.57 & 0.22 & 0.06 & 1.65 & 1.52 & 0.46 & 82 \\
\hline LIL & 0.21 & 0.13 & -0.08 & 0.72 & 0.80 & 2.82 & 1.64 & 0.17 & 0.10 & 1.80 & 2.04 & 0.39 & 105 \\
\hline KIS & 0.23 & 0.12 & -0.11 & 0.52 & 1.00 & 0.93 & 4.44 & 0.20 & 0.09 & 1.73 & 2.12 & 0.49 & 108 \\
\hline TOU & 0.16 & 0.06 & -0.10 & 0.61 & 1.07 & 1.81 & 5.86 & 0.14 & 0.05 & 1.76 & 1.89 & 0.27 & 89 \\
\hline VEN & 0.31 & 0.10 & -0.21 & 0.69 & 1.25 & 1.62 & 7.21 & 0.25 & 0.07 & 2.00 & 1.95 & 0.28 & 255 \\
\hline AVI & 0.18 & 0.06 & -0.12 & 0.68 & 0.81 & 1.36 & 2.70 & 0.14 & 0.05 & 1.94 & 0.05 & 0.50 & 251 \\
\hline BIA & 0.16 & 0.08 & -0.08 & 0.69 & 0.87 & 1.68 & 1.59 & 0.13 & 0.06 & 1.73 & 0.06 & 0.30 & 13 \\
\hline BOR & 0.19 & 0.08 & -0.11 & 0.65 & 0.81 & 2.00 & 2.21 & 0.16 & 0.06 & 1.74 & 0.06 & 0.30 & 166 \\
\hline BUC & 0.29 & 0.15 & -0.14 & 0.63 & 0.93 & 1.82 & 3.01 & 0.25 & 0.11 & 1.81 & 0.11 & 0.26 & 173 \\
\hline CLE & 0.09 & 0.19 & 0.10 & 0.59 & 0.42 & 0.80 & 0.06 & 0.08 & 0.17 & 2.07 & 0.17 & 0.54 & 15 \\
\hline CRE & 0.19 & 0.12 & -0.07 & 0.71 & 0.71 & 1.50 & 0.80 & 0.15 & 0.09 & 1.93 & 0.09 & 0.56 & 17 \\
\hline GOT & 0.12 & 0.05 & -0.07 & 0.76 & 0.95 & 1.47 & 3.08 & 0.10 & 0.04 & 2.06 & 0.04 & 0.59 & 84 \\
\hline HEL & 0.22 & 0.10 & -0.12 & 0.72 & 0.87 & 1.74 & 1.66 & 0.18 & 0.07 & 1.87 & 0.07 & 0.17 & 27 \\
\hline LEI & 0.28 & 0.12 & -0.16 & 0.68 & 0.85 & 1.35 & 2.48 & 0.23 & 0.09 & 1.86 & 0.09 & 0.39 & 97 \\
\hline LIL & 0.25 & 0.11 & -0.14 & 0.60 & 0.85 & 1.38 & 2.11 & 0.21 & 0.08 & 1.75 & 0.08 & 0.38 & 90 \\
\hline KIS & 0.24 & 0.10 & -0.14 & 0.64 & 0.92 & 1.39 & 2.26 & 0.20 & 0.07 & 1.89 & 0.07 & 0.24 & 167 \\
\hline MOS & 0.21 & 0.08 & -0.13 & 0.81 & 0.91 & 1.77 & 1.51 & 0.15 & 0.05 & 2.13 & 0.05 & 0.36 & 30 \\
\hline NOR & 0.10 & 0.06 & -0.04 & 0.62 & 1.06 & 2.07 & 2.63 & 0.09 & 0.04 & 1.66 & 0.04 & 0.80 & 71 \\
\hline OOS & 0.18 & 0.14 & -0.04 & 0.94 & 0.78 & 2.66 & 1.35 & 0.14 & 0.10 & 1.87 & 0.10 & 0.39 & 39 \\
\hline VEN & 0.29 & 0.09 & -0.20 & 0.79 & 0.78 & 1.86 & 1.65 & 0.22 & 0.07 & 2.13 & 0.07 & 0.32 & 178 \\
\hline VIN & 0.19 & 0.06 & -0.13 & 0.64 & 0.72 & 0.54 & 1.43 & 0.15 & 0.05 & 2.05 & 0.05 & 0.65 & 39 \\
\hline
\end{tabular}

results typically show a spring time maximum between April and June or some weeks earlier (KIS and VEN). This is reflected in the measurements at LIL, KIS and GOT, too, but it could not be seen at VEN and AVI. Such a spring time maximum in the AOD derived from lidar data was reported before by Matthias et al. (2004) for three different stations in Germany. Likewise, the authors didn't find this feature at lidar stations in southern Europe (Italy and Greece), either . There are two possible explanations for this maximum. First, it could be caused by biogenic aerosols or aerosol precursors emitted during the spring bloom of trees and plants which is more pronounced in central Europe than in south Europe. Second, ammonia emissions from fertilization in spring are concentrated in central Europe and they have their maximum in March/April. While ammonia emissions are included in the emission data base, the aerosols resulting from biogenic emissions are certainly underestimated in the model.

Better agreement between the model and the measurements is achieved in winter (October till March) compared to summer (April till September) which again corresponds to the results for the aerosol mass at ground level. At almost all stations the bias between the model results and the measurements is lower in winter than in summer. Only LEI, where no measurements before May 2001 are available, and the south European stations VEN and AVI show almost no difference between the seasons. The picture is unclear for the correlations during the different seasons. Considering only stations with more than 200 data points in both years, the east European stations BUC and KIS show clearly better correlations between measurements and model in winter months. Only slightly higher correlations in winter were detected for VEN and LIL, while at AVI the correlation was slightly lower in winter than in summer.

Distribution functions of the AOD values were investigated at six stations, AVI, BUC, GOT, LIL, KIS and VEN. At each of these stations measurements on more than 100 days in both years could be considered for the statistical evaluation. It is expected that measured AOD values follow a log-normal distribution (O'Neill et al., 2000; Matthias and Bösenberg, 2002; Behnert et al., 2007), here the distribution 

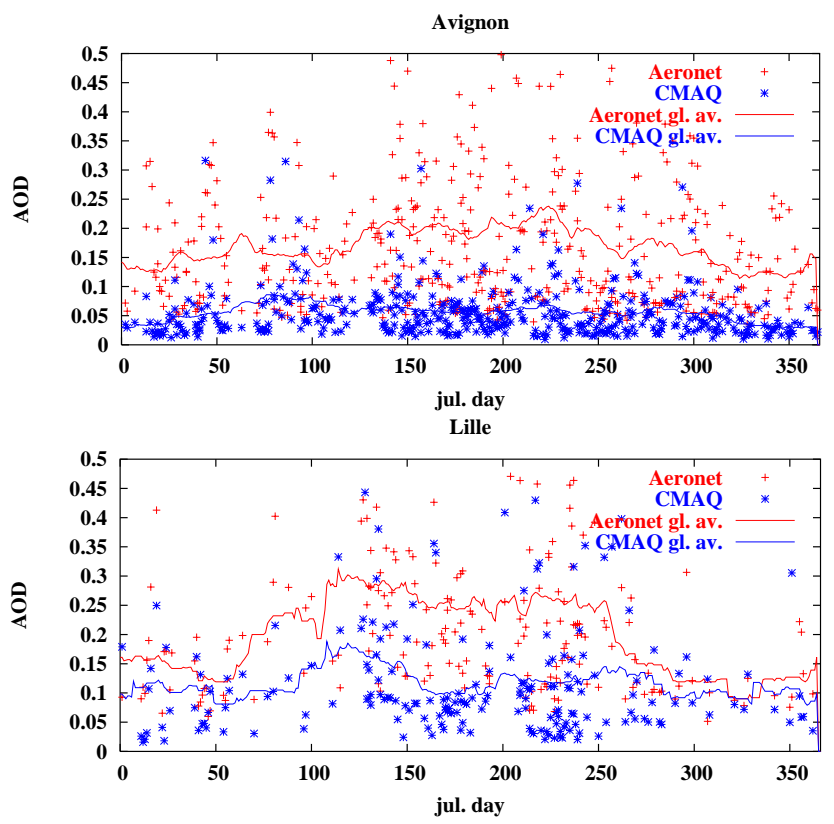

Fig. 8. Annual cycle (daily means and six weeks gliding average) of the aerosol optical depth at $500 \mathrm{~nm}$ at Lille and Avignon in 2000 and 2001: comparison of AERONET measurements with modelled values.

functions of the modelled AOD values are analysed, too. The same statistical tests as for the $\mathrm{PM}_{10}$ measurements were applied to the data-sets, the $\chi^{2}$-test and the KolmogoroffSmirnow-test (KS-test). Again 9 classes were chosen in the range of AOD values between 0.02 and 1 for the measurements and of 0.01 to 0.4 for the modelled values. Only at GOT, the range of AOD values was restricted to 0.02 to 0.6 for the measurements and 0.01 to 0.3 for the modelled values. The results are displayed in Table 10. The data from five of the stations, namely BUC, GOT, LIL, VEN and KIS can be very well represented by a log-normal distribution because they passed both tests on the $95 \%$ level. The data from AVI cannot be represented by a log-normal distribution on the given significance level as indicated by the $\chi^{2}$-test and this holds also for the modelled data at this station. Nevertheless, the results from the KS-test are below the threshold for the $95 \%$ confidence interval. Here, the measured distribution function looks bimodal (see Fig. 9), with small and large values being more frequent than the log-normal distribution would suggest. This can be interpreted as frequent events of very high optical depths caused e.g. by Saharan dust events. Similarly, the modelled aerosol optical depth values show that small values are more likely than expected and values around the median are underrepresented, however this effect is less pronounced than for the measurements. Saharan dust events influence the Mediterranean region quite frequently, the dust is mainly transported in high altitudes where it can travel over long distances. The model is not
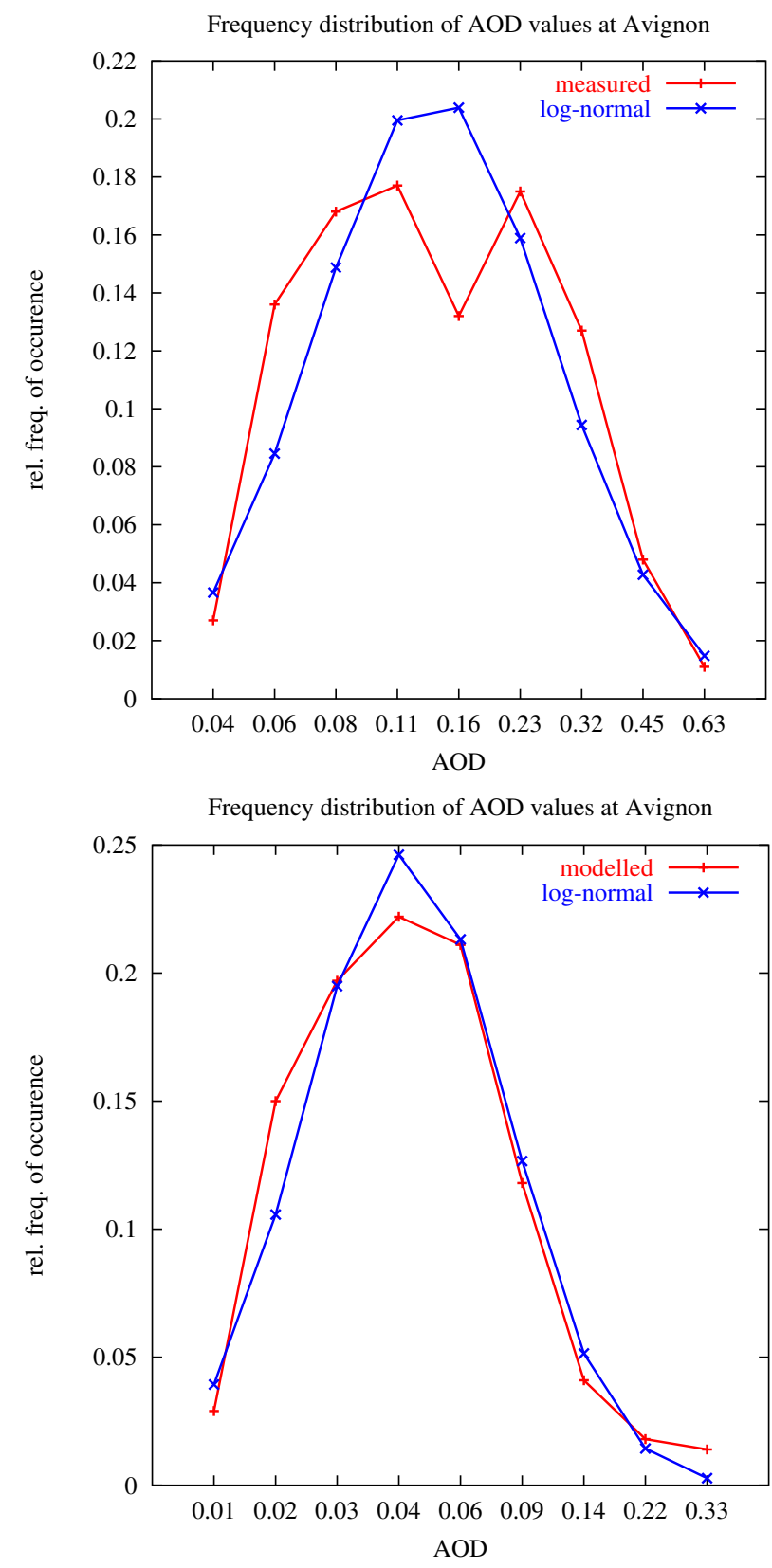

Fig. 9. Distribution function of the measured AOD values (left side) and modelled AOD values (right side) at Avignon together with an ideal log-normal distribution. The y-axis values represent the AOD values of the 9 logarithmically distributed classes.

able to capture these events correctly. First because the main source regions are outside the model domain and second because wind blown dust is only included in a rather crude way by considering ground level dust emissions from Aerocom (see Sect. 2.2). 
Table 10. Statistical measures of the AOD probability distribution function at stations where data from more than 100 days in 2000 and 2001 was available. Results of a test for a log-normal distribution on the $95 \%$ significance level ( $\chi^{2}$-test and KS-test, see text). Measured (mea.), modelled (mod.) and threshold (thr.) values are given. $\mathrm{PM}_{10}$ values are in $\mu \mathrm{g} / \mathrm{m}^{3}$. Bold numbers denote the test criteria were not met.

\begin{tabular}{lccccccccccc}
\hline \multirow{2}{*}{ Station } & \multicolumn{2}{c}{ median } & \multicolumn{2}{c}{ s } & \multicolumn{3}{c}{$\chi^{2}$} & \multicolumn{3}{c}{ KS } & N \\
& mea. & mod. & mea. & mod. & mea. & mod. & thr. & mea. & mod. & thr. & \\
\hline AVI & 0.14 & 0.04 & 0.65 & 0.67 & $\mathbf{4 5 . 1}$ & $\mathbf{3 0 . 8}$ & 14.07 & 0.054 & 0.031 & 0.065 & 441 \\
BUC & 0.23 & 0.11 & 0.59 & 0.74 & 4.6 & 3.5 & 14.07 & 0.018 & 0.024 & 0.094 & 208 \\
GOT & 0.09 & 0.04 & 0.74 & 0.70 & 4.8 & 2.3 & 14.07 & 0.042 & 0.019 & 0.124 & 121 \\
LIL & 0.19 & 0.09 & 0.58 & 0.75 & 10.7 & 7.4 & 14.07 & 0.051 & 0.028 & 0.097 & 195 \\
KIS & 0.20 & 0.08 & 0.60 & 0.80 & 6.1 & 4.4 & 14.07 & 0.035 & 0.017 & 0.065 & 433 \\
VEN & 0.24 & 0.07 & 0.72 & 0.71 & 5.5 & 10.8 & 14.07 & 0.019 & 0.025 & 0.082 & 275 \\
\hline
\end{tabular}

\section{Conclusions}

The aerosol distribution over Europe in 2000 and 2001 was simulated with the regional air quality model CMAQ (v4.5). A detailed comparison of the results with measured $\mathrm{PM}_{10}$ values close to ground and to columnar aerosol optical depth values was performed and presented in this paper. Although the model takes both natural and anthropogenic emissions into account, a significant underestimation of the measured $\mathrm{PM}_{10}$ values was found. At the five German stations, this effect was more pronounced in summer than in winter, while in Austria and Switzerland large differences were observed in all seasons. The investigation of the key chemical components of the aerosol particles (nitrate, sulfate, ammonium, sodium and chloride) at DE44 and NO01 gave a more detailed picture.

At DE44 good agreement between measured and modelled nitrate, sulfate and ammonium was found. Sodium and chloride showed good correlations but a large underestimation, most likely because the model does not represent the fine fraction of sea salt aerosols. The largest differences remained in the fraction of aerosol that could not be further specified by the measurements and that most likely consists of organic aerosol, primary coarse particles and water. These differences were much larger in summer than in winter and this suggests the conclusion that aerosols of biogenic origin, both primary and secondary particles, could be responsible for a large part of the discrepancies. In winter aerosol water may play an important role because relative humidities around $100 \%$ that may cause a huge water uptake of the aerosol particles are much more frequent in winter than in summer. This may lead to residual water sticking to the aerosol particles although it is assumed that they do not contain any water at $\mathrm{RH}=50 \%$. Primary coarse particle emissions seem to be still too low in the emission inventories.

At NO01 the picture is very similar to DE44 although here nitrate is significantly underestimated while sodium and chloride are overestimated. The largest differences of the chemically unspecified aerosol are again observed in summer with a clear focus on May and June leading to similar conclusions as for DE44. A comparison of the organic aerosol that has been measured since 2001 at NO01 showed that the model values are between a factor of 1.5 and 3 lower than the measurements. The time series of the inorganic aerosol showed reasonable correlation coefficients between 0.48 and 0.81 which gives a strong indication that the main transport patterns are represented by the model and that the dominant emission sources are correctly located. However, it cannot be totally excluded that at some places errors, e.g. in emissions and chemical transformations, cancel out.

Inorganic aerosol is captured well by the model, as comparisons to measurements at several EMEP stations show. On average all the main components sulfate, nitrate and ammonium are 15-20\% lower in the model than measured, but no clear regional features were observed, except for the by far largest deviations at Ispra (IT04) close to the Alpes in north Italy. Orographic features not covered by the model and eventually underestimated emissions might be the reasons for the discrepancies. Nitrate is not modelled well in remote areas and sulfate is underestimated in Germany and Denmark. Here, ship emissions that were not considered in the emission data might contribute significantly to the sulfate concentrations, at least in Denmark and the northern part of Germany. However the temporal behaviour is captured quite well at many stations as represented by correlation coefficients between 0.4 and 0.7 .

Most of the findings agree well with those reported for CMAQ studies in the US (Tesche et al., 2006; Boylan and Russell, 2006; Eder and Yu, 2006; McKeen et al., 2007; Mathur et al., 2008), e.g. the summer/winter differences in the model performance for nitrate and ammonium and the underestimation of $\mathrm{OC}$. The underestimation of the total aerosol mass is more obvious in this study, but in the US mostly $\mathrm{PM}_{2.5}$ is considered while in Europe the focus is still on $\mathrm{PM}_{10}$.

The underestimation of aerosol mass by typically 30$60 \%$ on the annual average consequently leads to much lower aerosol optical depth values than observed within the 
AERONET sunphotometer network. Particularly at south European stations the modelled AOD values are less than $50 \%$ of the measured ones. One reason might be that organic aerosol particles are of much higher importance at higher temperatures because the emissions of the precursors isoprene and terpenes depend on temperature and sunlight. The other reason is that coarse particles, that are of primary origin are not adequately represented in the emission inventories. Saharan dust events for example, which are quite frequent in the Mediterranean cannot be captured by the model because the main source regions are outside of the domain and these emissions were not considered. The correlation coefficients are typically between 0.3 and 0.5 which is lower than for the $\mathrm{PM}_{10}$ time series. This can be explained by the fact that the relative humidity plays an important role for the size of the aerosols and therefore for the optical properties. $\mathrm{RH}$ must be considered as an important additional source of uncertainty when optical aerosol parameters are considered in model evaluations.

Despite the significant underestimation of the modelled AOD values, their distribution functions follow a log-normal distribution at most of the stations, which is the same as the measurements do. Noteworthy, at stations where the applied statistical tests indicated deviations from the log-normal distribution, this was also true for the modelled values. Obviously, the variability of the AOD values, may it be caused by transport, humidity, emissions or particle formation, is correctly reproduced by the model, while the magnitude of the values is too low. At Avignon the most significant deviations from the log-normal distribution were observed. One possible reason is that Saharan dust events frequently lead to high optical depth values that cause a distortion of the distribution function.

The picture is slightly different for the distribution functions of the $\mathrm{PM}_{10}$ values at ground. Here, the measurements mostly follow a log-normal distribution but particularly at elevated sites this doesn't hold for the modelled values. The model results from the nested grid with higher horizontal resolution give a reduced bias between model and measurements at coastal stations, however the correlation coeffcients are in most cases lower than for the coarser grid resolution. The distribution functions do not show closer agreement to a log-normal distribution at elevated sites in the nested grid. These results imply that the main reasons for the day-to-day variability of the aerosol concentrations are already captured on the $54 \times 54 \mathrm{~km}^{2}$ scale and that a higher resolved land use information on the $18 \times 18 \mathrm{~km}^{2}$ grid lead to a reduced bias at coastal stations.

The CMAQ model was able to represent the aerosol distribution over Europe and the variability of daily mean values on a $54 \times 54 \mathrm{~km}^{2}$ and a $18 \times 18 \mathrm{~km}^{2}$ grid. The total amount of atmospheric aerosol is still significantly underestimated by the model. The analysis of the chemical composition at two sites indicated that this discrepancy is most likely related to organic aerosol particles and to a missing coarse aerosol frac- tion. On the one hand the direct emissions of these aerosols and of their precursors may be underestimated, at least reliable data for regional modeling purposes is still missing. On the other hand, there is still a lot of research and development needed to improve secondary organic aerosol formation in chemistry transport models. In south Europe Saharan dust will play an important role as well and regional models covering whole Europe should consider this important source of particles. If particle mass would be correctly captured, this study indicates that model derived aerosol optical depth values over Europe could be gained from model results to study their effects on regional climate.

To further improve the results of the aerosol modeling with CMAQ the emission inventories that are used for the model runs will be amended to include a larger fraction of the primary coarse particles, primary biogenic particles and the biogenic precursors. Because a lot of work is already done with respect to SOA modeling, future versions of CMAQ will certainly include optimized algorithms to better treat this challenging problem. Finally, CMAQ will be used for multiannual runs to determine the development of the distribution of aerosol particles and of particle bound pollutants like benzo(a)pyrene in Europe over the last decades.

Acknowledgements. I thank US EPA for the use of CMAQ and NCAR/Penn State University for the use of MM5. Ground data was provided by EMEP, additional data that has been collected within the EU FP5 project CREATE (contract No. EVK2-CT2002-00173), thanks to K. Müller for the data from Melpitz and to T. Krognes for the data from Birkenens.

I gratefully acknowledge the use of AERONET data (http://aeronet.gsfc.nasa.gov) and PHOTONS data (http: //www-loa.univ-lille1.fr/photons). Thanks to the PIs G. Sappe (Avignon, PHOTONS), D. Guyon (Bordeaux, PHOTONS), D. Tanré (Bucarest, Clermont Ferrand, Toulouse, Vinon, Biarritz, PHOTONS), B. Chatenet (Creteil, PHOTONS), B. Hakansson (Gotland, AERONET), J. Bösenberg, (Hamburg, AERONET), R. Doerffer (Helgoland, AERONET), Albert Ansmann (Leipzig, AERONET), P. Goloub (Lille, PHOTONS), B. Holben (Moscow, Kishinev, AERONET), N. Chubarova (Moscow, AERONET), S. Kratzer (Norrkoeping, AERONET), K. Ruddick (Oostende, PHOTONS), and G. Zibordi (Venice, AERONET).

Edited by: G. McFiggans

\section{References}

Aulinger, A., Matthias, V., and Quante, M.: Introducing a partitioning mechanism for PAHs into the Community Multiscale Air Quality modelling system and its application to simulating the transport of benzo(a)pyrene over Europe, J. Appl. Meteor., in press, 2007.

Behnert, I., Matthias, V., and Doerffer, R.: Aerosol climatology from ground-based measurements for the southern North Sea, Atmos. Res., 84, 201-220, doi:10.1016/j.atmosres.2006.05.006, 2007. 
Binkowski, F. and Roselle, S.: Models-3 Community Multiscale Air Quality (CMAQ) model aerosol component. 1. Model description, J. Geophys. Res., 108, 4183, doi:10.1029/2001JD001409, 2003.

Bond, T. C., Streets, D. G., Yarber, K. F., Nelson, S. M., Woo, J. H., and Klimont, Z.: A technology-based global inventory of black and organic carbon emissions from combustion, J. Geophys. Res.-Atmos., 109, D14203, doi:10.1029/2003JD003697, 2004.

Boylan, J. W. and Russell, A. G.: PM and light extinction model performance metrics, goals, and criteria for three-dimensional air quality models, Atmos. Environ., 40, 4946-4959, 2006.

Byun, D. and Ching, J.: Science Algorithms of the EPA Models-3 Community Multiscale Air Quality Modeling System, Epa/600/r-99/030, US Environmental Protection Agency, Office of Research and Development, Washington DC, 1999.

Byun, D. and Schere, K.: Review of the Governing Equations, Computational Algorithms, and Other Components of the Models-3 Community Multiscale Air Quality (CMAQ) Modeling System, Applied Mechanics Reviews, 59, 51-77, 2006.

Chen, F. and Dudhia, J.: Coupling an advanced landsurface/hydrology model with the Penn State/NCAR MM5 modeling system. Part I: Model implementation and sensitivity, Mon. Weather Rev., 129, 569-585, 2001.

Colle, B., Olson, J., and Tongue, J.: Multiseason Verification of the MM5. Part II: Evaluation of High-Resolution Precipitation Forecasts over the Northeastern United States, B. Am. Meteorol. Soc., 18, 458-480, 2003.

Cooke, W. F. and Wilson, J. J. N.: A global black carbon aerosol model, J. Geophys. Res.-Atmos., 101, 19395-19409, 1996.

Denier van der Gon, H., van het Bolscher, M., Visschedijk, A., and Zandveld, P.: Study of the effectiveness of UNECE Persistent Organic Pollutants Protocol and cost of possible additional measures. Phase I: Estimation of emission reduction resulting from the implementation of the POP Protocol, TNO report B\& O-A R 2005/194, TNO, Laan van Westenenk 501, P.O. Box 342, 7300 AH Appeldoorn, The Netherlands, 2005.

Dentener, F., Kinne, S., Bond, T., Boucher, O., Cofala, J., Generoso, S., Ginoux, P., Gong, S., Hoelzemann, J. J., Ito, A., Marelli, L., Penner, J. E., Putaud, J., Textor, C., Schulz, M., van der Werf, G. R., and Wilson, J.: Emissions of primary aerosol and precursor gases in the years 2000 and 1750 prescribed data-sets for AeroCom, Atmos. Chem. Phys., 6, 4321-4344, 2006, http://www.atmos-chem-phys.net/6/4321/2006/.

EC: Directive 2004/107/EC of the European Parliament and of the Council of 15 December 2004 relating to arsenic, cadmium, mercury, nickel and polycyclic aromatic hydrocarbons in ambient air, Official journal of the european union, EC, 26.01.2005, 2005.

Eck, T. F., Holben, B. N., Reid, J. S., Dubovik, O., Smirnov, A., O'Neill, N. T., Slutsker, I., and Kinne, S.: Wavelength dependence of the optical depth of biomass burning, urban and desert dust aerosols, J.Geophys. Res., 104, 31 333-31 350, 1999.

Eder, B. and Yu, S.: A performance evaluation of the 2004 release of Models-3 CMAQ, Atmos. Environ., 40, 4811-4824, 2006.

Friedrich, R. and Reis, S.: Emissions of air pollutants, Springer, Berlin Heidelberg New York, 2004.

Fuzzi, S., Andreae, M., Huebert, B., Kulmala, M., Bond, T., Boy, M., Doherty, S., Guenther, A., Kanakidou, M., Kawamura, K., Kerminen, V.-M., Lohmann, U., Russell, L., and Pöschl, U.:
Critical assessment of the current state of scientific knowledge, terminology, and research needs concerning the role of organic aerosols in the atmosphere, climate, and global change, Atmos. Chem. Phys., 6, 2017-2038, 2006,

http://www.atmos-chem-phys.net/6/2017/2006/.

Gery, M. W., Whitten, G. Z., Killus, J. P., and Dodge, M. C.: A photochemical kinetics mechanism for urban and regional scale computer modeling, J. Geophys. Res., 94, 12925 - 12 956, 1989.

Gilliam, R., Hogrefe, C., and Rao, S. T.: New methods for evaluating meteorological models used in air quality applications, Atmos. Environ., 40, 5073-5086, 2006.

Granier, C., Guenther, A., Lamarque, J. F., Mieville, A., Müller, J. F., Olivier, J., Orlando, J., Peters, J., Petron, G., Tyndall, G., and Wallens, S.: POET, a database of surface emissions of ozone precursors, http://www.aero.jussieu.fr/projet/ACCENT/ POET.php, 2005.

Grell, G., Dudhia, J., and Stauffer, D. R.: A Description of the FifthGeneration Penn State/NCAR Mesoscale Model (MM5), Ncar technical note 398, NCAR, Boulder, Colorado, USA, 1995.

Holben, B. N., Eck, T. F., Slutsker, I., Tanré, D., Buis, J. P., Setzer, A., Vermote, E., Reagan, J. A., Kaufman, Y. J., Nakajima, T., Lavenu, F., Jankowiak, I., and Smirnov, A.: AERONET- A Federated Instrument Network and Data Archive for Aerosol Characterization, Remote Sens. Environment, 66, 1-16, 1998.

Holben, B. N., Tanré, D., Smirnov, A., Eck, T. F., Slutsker, I., Abuhassan, N., Newcomb, W., Schafer, J., Chatenet, B., Lavenue, F., Kaufman, Y. J., Van de Castle, J., Setzer, A., Markham, B., Clark, D., Frouin, R., Halthore, R., Karnieli, A., O'Neill, N. T., Pietras, C., Pinker, R. T., Voss, K., and Zibordi, G.: An emerging ground-based aerosol climatology: Aerosol Optical Depth from AERONET, J. Geophys. Res., 106, 12 067-12097, 2001.

Hong, S. Y. and Pan, H. L.: Nonlocal boundary layer vertical diffusion in a Medium-Range Forecast Model, Monthly Weather Review, 124, 2322, 1996.

Horowitz, L. W., Walters, S., Mauzerall, D. L., Emmons, L. K., Rasch, P. J., Granier, C., Tie, X., Lamarque, J.-F., Schultz, M. G., Tyndall, G. S., Orlando, J. J., and Brasseur, G. P.: A global simulation of tropospheric ozone and related tracers: Description and evaluation of MOZART, version 2, J. Geophys Res, 108, 4784, doi:10.1029/2002JD002853, 2003.

Houyoux, M. R. and Vukovich, J. M.: Updates to the Sparse Matrix Operator Kernel Emission (SMOKE) Modeling System and Integration With Models-3, in: The Emission Inventory: Regional Strategies for the Future, 1999.

Jakobs, H. J., Feldmann, H., Hass, H., and Memmesheimer, M. The use of nested models for air pollution studies: an application of the EURAD model to a SANA episode, J. Appl. Met., 34, 1301-1319, 1995.

Kahnert, M. and Tarrason, L.: Transboundary particulate matter in Europe. Status report 4/2003, Joint ccc \& msc-w \& ciam report 2003, Norwegian Institute for Air Research, Kjeller, Norway, 2004.

Kain, J. and Fritsch, J. M.: Convective parameterisation for mesoscale models: The Kain-Fritsch scheme, in: The representation of cumulus convection in numerical models, Amer. Met. Soc., 24, p. 165, 1993.

Kain, J. S.: The Kain-Fritsch Convective Parameterization: An Update, J. Appl. Meteorol., 43, 170-181, 2004. 
Kanakidou, M., Seinfeld, J., Pandis, S., Barnes, I., Dentener, F., Facchini, M., Van Dingenen, R., Ervens, B., Nenes, A., Nielsen, C., Swietlicki, E., Putaud, J., Balkanski, Y., Fuzzi, S., Horth, J., Moortgat, G., Winterhalter, R., Myhre, C., Tsigaridis, K., Vignati, E., Stephanou, E., and Wilson, J.: Organic aerosol and global climate modelling: A review, Atmos. Chem. Phys., 5, 1053-1123, 2005,

http://www.atmos-chem-phys.net/5/1053/2005/.

Kinne, S., Lohmann, U., Feichter, J., Schulz, M., Timmreck, C., Ghan, S., Easter, R., Chin, M., Ginoux, P., Takemura, T., Tegen, I., Koch, D., Herzog, M., Penner, J., Pitari, G., Holben, B., Eck, T., Smirnov, A., Dubovik, O., Slutsker, I., Tanré, D., Torres, O., Mishchenko, M., Geogdzhayev, I., Chu, D., and Kaufman, Y.: Monthly averages of aerosol properties: A global comparison among models, satellite data, and AERONET ground data, J. Geophys. Res., 108, 4634, doi:10.1029/2001JD001253, 2003.

Kupiainen, K. and Klimont, Z.: Primary emissions of fine carbonaceous particles in Europe, Atmos. Environ., 41, 2156-2170, 2007.

Malm, W. C., Sisler, J. F., Huffman, D., Eldred, R. A., and Cahill, T. A.: Spatial and seasonal trends in particle concentration and optical extinction in the United States, J. Geophys. Res., 99, 1347-1370, 1994.

Mathur, R., Yu, S., Kang, D., and Schere, K. L.: Assessment of the wintertime performance of developmental particulate matter forecasts with the Eta-Community Multiscale Air Quality modeling system, J. Geophys. Res.-Atmos., 113, D02303, doi:10.1029/2007JD008580, 2008.

Matthias, V. and Bösenberg, J.: Aerosol climatology for the planetary boundary layer derived from regular lidar measurements, Atmos. Res., 63, 221-245, 2002.

Matthias, V., Balis, D., Bösenberg, J., Eixmann, R., Iarlori, M., Komguem, L., Mattis, I., Papayannis, A., Pappalardo, G., Perrone, M. R., and Wang, X.: The Vertical Aerosol Distribution over Europe: Statistical Analysis of Raman Lidar Data from 10 EARLINET Stations, J. Geophys. Res., 109, D18201, doi:10.1029/2004JD004638, 2004.

Matthias, V., Aulinger, A., and Quante, M.: Adapting CMAQ to investigate air pollution in North Sea coastal regions, Environmental Modelling and Software, 23, 356-368, doi:10.1016/j.envsoft.2007.04.010, 2008.

McKeen, S., Chung, S. H., Wilczak, J., Grell, G., Djalalova, I., Peckham, S., Gong, W., Bouchet, V., Moffet, R., Tang, Y., Carmichael, G. R., Mathur, R., and Yu, S.: Evaluation of several PM2.5 forecast models using data collected during the ICARTT/NEAQS 2004 field study, J. Geophys. Res.-Atmos., 112, D10S20, doi:10.1029/2006JD007608 2007.

Neusüß, C., Weise, D., Birmili, W., Wex, H., Wiedensohler, A., and Covert, D. S.: Size-segregated chemical, gravimetric and number distribution-derived mass closure of the aerosol in Sagres, Portugal during ACE-2, Tellus, 52B, 169-184, 2000.

Niemeier, U., Granier, C., Kornblueh, L., Walters, S., and Brasseur, G. P.: TGlobal impact of road traffic on atmospheric chemical composition and on ozone climate forcing, J. Geophys. Res., 111, D09301, doi:10.1029/2005JD006407, 2006.

O’Neill, N. T., Ignatov, A., Holben, B. N., and Eck, T. F.: The lognormal distribution as a reference for reporting aerosol optical depth statistics; Empirical tests using multi-year, multi-site AERONET sunphotometer data, Geophys. Res. Lett., 27(20),
3333-3336, 2000.

Otte, T. L.: Science Algorithms of the EPA Models-3 Community Multiscale Air Quality Modeling System, chap. Developing meteorological fields, EPA/600/R-99/030, US Environmental Protection Agency, Office of Research and Development, Washington DC, 1999.

Penner, J. E., Andreae, M., Annegarn, H., Barrie, L., Feichter, J., Hegg, D., Jayaraman, A., Leaitch, R., Murphy, D., Nganga, J., and Pitari, G.: Aerosols, their Direct and Indirect Effects, in: Climate Change 2001: The Scientific Basis, Contribution of Working Group I to the Third Assessment Report of the Intergovernmental Panel on Climate Change (IPCC), edited by Houghton, J. T., Ding, Y., Griggs, D. J., Noguer, M., v. d. Linden, P. J., and Xiaosu, D., chap. 5, 289-348, Cambridge University Press, Cambridge, 2001.

Pun, B. K., Wu, S. Y., Seigneur, C., Seinfeld, J. H., Griffin, R. J., and Pandis, S. N.: Uncertainties in modeling secondary organic aerosols: Three-dimensional modeling studies in Nashville/Western Tennessee, Environmental Science \& Technology, 37, 3647-3661, 2003.

Putaud, J.-P., Van Dingenen, R., Mangoni, M., Virkkula, A., Raes, F., Maring, H., Prospero, J. M., Swietlicki, E., Berg, O. H., Hillamo, R., and Mäkelä, T.: Chemical mass closure and assessment of the origin of the submicron aerosol in the marine boundary layer and the free troposphere at Tenerife during ACE2, Tellus, 52B, 147-168, 2000.

Putaud, J.-P., Raes, F., Van Dingenen, R., Bruggemann, E., Facchini, M. C., Decesari, S., Fuzzi, S., Gehrig, R., Huglin, C., Laj, P., Lorbeer, G., Maenhaut, W., Mihalopoulos, N., Müller, K., Querol, X., Rodriguez, S., Schneider, J., Spindler, G., ten Brink, H., Torseth, K., and Wiedensohler, A.: European aerosol phenomenology 2: chemical characteristics of particulate matter at kerbside, urban, rural and background sites in Europe, Atmospheric Environment, 38, 2579-2595, 2004.

Ramaswamy, V., Boucher, O., Haigh, J., Hauglustaine, D., Haywood, J., Myhre, G., Nakajima, T., Shi, G. Y., and Solomon, S.: Radiative forcing of climate change, in: Climate Change 2001: The Scientific Basis, Contribution of Working Group I to the Third Assessment Report of the Intergovernmental Panel on Climate Change (IPCC), edited by Houghton, J. T., Ding, Y., Griggs, D. J., Noguer, M., v. d. Linden, P. J., and Xiaosu, D., chap. 6, pp. 349-416, Cambridge University Press, Cambridge, 2001.

Reisner, J., Rasmussen, R. J., and Bruintjes, R. T.: Explicit forecasting of supercooled liquid water in winter storms using the MM5 mesoscale model, Quaterly Journal of the Royal Meteorological Society, 124B, 1071, 1998.

Schell, B., Ackermann, I. J., Hass, H., Binkowski, F. S., and Ebel, A.: Modelling the formation of secondary organic aerosol within a comprehensive air quality model system, J. Geophys. Res., 2106, 28 275-28 293, 2001.

Sokhi, R. S., José, R. S., Kitwiroon, N., Fragkou, E., Pérez, J. L., and Middleton, D. R.: Prediction of ozone levels in London using the MM5-CMAQ modelling system, Environmental Modelling \& Software, 21, 566-576, 2006.

Stockwell, W. R., Middleton, P., and Chang, J. S.: The second generation regional acid deposition model chemical mechanism for regional air quality modeling, J. Geophys. Res., 95, $16343-$ $16367,1990$. 
Tesche, T., Morris, R., Tonnesen, G., McNally, D., Boylan, J., and Brewer, P.: CMAQ/CAMx annual 2002 performance evaluation over the eastern US, Atmospheric Environment, 40, 4906-4919, 2006.

Textor, C., Schulz, M., Guibert, S., Kinne, S., Balkanski, Y., Bauer, S., Berntsen, T., Berglen, T., Boucher, O., Chin, M., Dentener, F., Diehl, T., Easter, R., Feichter, H., Fillmore, D., Ghan, S., Ginoux, P., Gong, S., Grini, A., Hendricks, J., Horowitz, L., Huang, P., Isaksen, I., Iversen, T., Kloster, S., Koch, D., Kirkevag, A., Kristjansson, J. E., Krol, M., Lauer, A., Lamarque, J. F., Liu, X., Montanaro, V., Myhre, G., Penner, J. E., Pitari, G., Reddy, S., Seland, O., Stier, P., Takemura, T., and Tien, X.: Analysis and quantification of the diversities of aerosol life cycles within AeroCom, Atmos. Chem. Phys., 6, 1777-1813, 2006, http://www.atmos-chem-phys.net/6/1777/2006/.

Troen, I. and Mahrt, L.: A simple model of the atmospheric boundary layer: Sensitivity to surface evaporation, Bound. Lay Met., 37, 129, 1986.
Twomey, S. A.: The influence of pollution on the shortwave albedo of clouds, J. Atmos. Sci., 34, 1149-1152, 1977.

van der Werf, G. R., Randerson, J. T., Giglio, L., Collatz, G. J., and Kasibhatla, P. S.: Interannual variability in global biomass burning emission from 1997 to 2004, Atmos. Chem. Phys., 6, 3423-3441, 2006,

http://www.atmos-chem-phys.net/6/3423/2006/.

Vestreng, V. and Klein, H.: Emission data reported to UNECE/EMEP: Quality Assurance and Trend Analysis \& Presentation of WebDab, Emep/msc-w note 1/2002, Norwegian Meteorological Institute, Oslo, Norway, 2002.

Yin, D., Jiang, W., Roth, H., and Giroux, E.: Improvement of biogenic emissions estimation in the Canadian Lower Fraser Valley and its impact on particulate matter modeling results, Atmos. Environ., 38, 507-521, 2004. 